DEMOGRAPHIC RESEARCH

VOLUME 43, ARTICLE 10, PAGES 245-284
PUBLISHED 24 JULY 2020

http://www.demographic-research.org/Volumes/Vol43/10/

DOI: 10.4054/DemRes.2020.43.10

Research Article

\title{
The long-run effects of poverty alleviation resettlement on child development: Evidence from a quasi-experiment in China
}

Lue Zhan

Jipeng Zhang

\section{Chong Lu}

This publication is part of the Special Collection on Life-Course Decisions of Families in China, organized by Guest Editors Bing Xu, William A.V. Clark, Eric Fong, and Li Gan.

(C) 2020 Lue Zhan, Jipeng Zhang \& Chong Lu.

This open-access work is published under the terms of the Creative Commons Attribution 3.0 Germany (CC BY 3.0 DE), which permits use, reproduction, and distribution in any medium, provided the original author(s) and source are given credit.

See https://creativecommons.org/licenses/by/3.0/de/legalcode. 


\section{Contents}

$\begin{array}{lll}1 & \text { Introduction } & 246\end{array}$

$2 \quad$ Background and hypotheses 249

$\begin{array}{lll}2.1 & \text { The poverty alleviation resettlement experiment } & 249\end{array}$

2.2 Hypotheses regarding the impact of PAR 250

3 Data 252

3.1 Sample selection and data collection 252

3.2 Balance tests 253

3.3 Data description and summary statistics 254

3.3.1 Education outcome 256

3.3.2 Income and employment in adulthood 257

$\begin{array}{ll}\text { 3.3.3 Marriage and fertility } & 258\end{array}$

$\begin{array}{ll}\text { 3.3.4 Living environment } 258 & 258\end{array}$

$4 \quad$ Empirical methodology and results $\quad 259$

4.1 Compliance rate and educational outcomes 260

4.2 Income and occupation choice in adulthood 262

4.2.1 Income in adulthood 262

4.2.2 Occupation choice 264

4.2.3 Marriage and fertility 265

4.3 Living environment in adulthood 265

5 Conclusions and policy implications 266

$\begin{array}{lll}6 & \text { Acknowledgments } & 268\end{array}$

References $\quad 269$

$\begin{array}{ll}\text { Appendix } & 274\end{array}$ 


\title{
The long-run effects of poverty alleviation resettlement on child development: Evidence from a quasi-experiment in China
}

\author{
Lue Zhan ${ }^{1}$ \\ Jipeng Zhang ${ }^{2,3}$ \\ Chong $\mathrm{Lu}^{2}$
}

\begin{abstract}

\section{BACKGROUND}

Poverty alleviation resettlement (PAR) program has become an important approach adopted by Chinese government to deal with rural poverty. Earlier programs were experimented for decades; we study a PAR program implemented by a local government in 1994.
\end{abstract}

\section{OBJECTIVE}

This research aims to study the effects of the PAR program on the long-run development of children from a life course perspective.

\section{METHODS}

We adopted a quasi-experimental design, by comparing the experimental group with a control group, using information of children's long-run outcomes from field survey and government archive.

\section{RESULTS}

We find that girls are worse off both in terms of education outcome and individual earnings in adulthood. Boys are less likely to be affected by the PAR experiment, but their earnings in adulthood are worse than those in the control group.

\section{CONCLUSIONS}

Overall, the results of the PAR experiment are not positive, for which we provide some possible explanations. Easier job access might discourage long-term investment in education. The PAR program might have short-term economic benefits but the longterm impact could be negative because of constrained choice of employment and location-specific skill accumulation that later can become less beneficial.

\footnotetext{
${ }^{1}$ School of Public Finance and Taxation, Nanjing University of Finance and Economic, Nanjing, China.

${ }^{2}$ Southwestern University of Finance and Economics, China.

${ }^{3}$ Corresponding author. Email: jpzhang@swufe.edu.cn.
} 


\section{CONTRIBUTION}

The paper investigates the potential bad consequences of poverty alleviate resettlement on children's long-run development. From a policy perspective, in the program we studied, people in the treated group are simply resettled to a designated area. A "one to many" relocation with free destination choices might be better.

\section{Introduction}

During forty years of reform and development from 1978 to 2018 , the poverty rate in rural China decreased from $97.5 \%$ to $1.7 \%$, according to China's state office of poverty alleviation and development. The poverty alleviation resettlement (PAR) program adopted by the Chinese government has become an important approach to dealing with rural poverty and growing rural-urban inequality. PAR is a government-sponsored, voluntary resettlement program, first experimented with in the early 1980s as a pilot program in the western regions of the Loess Plateau (Xue, Wang, and Xue 2013). ${ }^{4}$ In many provinces, local governments initiate PAR programs by encouraging people living in remote mountainous areas with limited resources and limited access to transportation to resettle in urban or suburban areas with better living conditions and more job opportunities.

In 2015 the Chinese government initiated nationwide PAR programs as part of its massive anti-poverty campaign. Financial incentives such as housing allowances and moving compensation/subsidies are provided to the moving families. According to the National Development and Reform Commission, by 2015 twelve million people had been relocated and between 2015 and 2020 another ten million people will have been relocated to new places with better public services and resources (Zhu and Ma 2016; Lo and Wong 2018). Despite such an aggressive expansion of the PAR program there has been little information regarding empirical questions, such as: What is the impact of the PAR resettlement from a life course perspective? Will PAR benefit the long-run development of the second generation (hereafter 'children')? These are the questions we aim to answer to provide empirical insight.

We study a PAR experiment implemented in 1994 in a mountainous area of the Boshan district of Zibo prefecture in the middle of Shandong Province and evaluate its impact on children's long-term development in adulthood. The Boshan experiment provides a rich empirical context and sufficiently long time period to study the relation between resettlement and child development. The experiment and its implementation

\footnotetext{
${ }^{4}$ This program resulted in the resettlement of nearly half a million impoverished farmers.
} 
are comparable to the practice elsewhere in China and in other countries. We investigate child development along the following dimensions: education choice, income and career selection, marriage and fertility, and living environment in adulthood.

Most of the current literature evaluating PAR focuses on the short-term impact since the data is more available. PAR has been shown to have an effect on poverty alleviation for the first-generation migrant, as measured by family income and working opportunities (Ning, Yin, and Wang 2018; Yin, Wang, and Wand 2017). Due to lack of long-term observational data, little has been done to study how the PAR program affects human capital development for future generations, especially in the Chinese context.

The most relevant literature comprises studies on the Moving to Opportunity (MTO) experiment and public housing demolition in the United States in the 1990s, whose purpose was to offer low-income families better living conditions. Chetty and colleagues (2016a) show strong evidence that the Moving To Opportunity (MTO) program provided economic gains by improving the human development of children whose families moved to a low-poverty area before they reached the age of thirteen. They investigate the impact of MTO on children in the long term through five dimensions: voucher take-up rate, income in adulthood, college attendance and quality, marriage and fertility, and neighborhood characteristics in adulthood. Jacob (2004), Kling, Ludwig, and Katz (2005), and Chyn (2018) investigate separately the short-run and long-run impacts of public housing demolitions in Chicago. They find that the program had a limited impact in the short run but has a prominent positive effect in the long run for young children. Bazzi et al. (2016) investigate the effect of Indonesia's government-sponsored, rural-to-rural transmigration program on villagers' productivity. They find that regional productivity differences and spatial skill matching are important for understanding the first generation's potential gains from migration.

There are important differences between MTO and the Boshan PAR. First, the MTO experiment helped families living in high-poverty urban communities to move to low-poverty communities. Generally, the high-poverty communities in the MTO program had high crime rates and low-quality schools, whereas in the Boshan PAR the major difference is that in the remote mountainous area there is less access to job opportunities. Before relocation the income inequality in the villages was insignificant and most people were farmers. Second, the moving schemes are different. In the MTO experiment the moving households had free choice of destination, while the Boshan PAR was a 'one-to-one'-type relocation: that is, the relocation was from one village to another designated village. 
Our paper contributes to the broad literature on migration and human development. DeLuca and Rosenblatt (2017) use new data from the Thompson desegregation case $\mathrm{e}^{5}$ in Baltimore. They find that families moved to more integrated and affluent neighborhoods, in school districts with more qualified teachers and fewer poor students, and most families stayed in these neighborhoods beyond their initial lease-up period. Similarly, $40 \%$ of housing voucher users had moved to a new house, and most voucher users believed their house, neighborhood, and overall global living situation had improved since relocation (Brooks et al. 2005). Chetty and Hendren (2018) study more than seven million families who moved across commuting zones and counties in the United States and show that the neighborhoods in which children grow up shape their earnings, college attendance rates, and fertility and marriage patterns. Bergman et al. (2019) use a randomized controlled trial with housing voucher recipients in Seattle and King County in Washington state and find that the intervention increased the fraction of families who moved to high-upward-mobility areas from $14 \%$ in the control group to $54 \%$ in the treatment group. Davis, Gregory, and Hartley (2019) use model simulations to quantify the impact of newly built low-income housing units placed in any given tract on the adult earnings of the children of the households who occupy those units. Adding low-income housing units generates a positive aggregate impact on children's later earnings, which tend to be higher and have higher Opportunity Atlas value-added measures.

In the Chinese context, Wang et al. (2017) estimate the effects of parents' rural-tourban migration on education among grade 5 students in urban and rural China. The results show that migrating with parents and attending private migrant schools in urban areas has a large and significant negative effect on students' math scores. Migrant students also exhibit higher levels of learning anxiety. Similarly, Yue et al. (2020) study the effects of maternal migration on the development, health, and nutrition outcomes of children in rural China. The results show that any maternal migration during early childhood reduces cognitive development and child nutrition. Overall, there is a sizable adverse effect of exposure to parental migration on the health and education outcomes of boys (Meng and Yamauchi 2017). However, Xu and Xie (2015) estimate the effects of migration on 10-15-year-old children from a 2010 national survey in China and find that children's migration has significant positive effects on their objective well-being.

We find that the Boshan PAR experiment has a negative impact on children's development in terms of educational outcome, living environment, and income in adulthood. The PAR program has heterogeneous effects across gender. It has as negative impact on girls by decreasing their high school entrance exam participation rate and increasing school dropout rates. These findings are in contrast to the positive

\footnotetext{
${ }^{5}$ It is known as the Baltimore Housing Mobility Program (BHMP) that helped families move to low-poverty, non-segregated neighborhoods with higher performing school districts.
} 
effects found in the studies on MTO and public housing demolition. This suggests that a 'one-to-many' relocation with free choice of destination might be better. The constrained choice of employment and location-specific skill accumulation can become disadvantageous. Easier job access might also provide a negative incentive to invest long-term in education, which could hurt relocated children in the long run.

Another mechanism underlying our findings is related to the spatial mismatch hypothesis pioneered by Kain (1968) to study issues related to residential segregation, economic restructuring, and suburbanization (Kasarda 1985, 1988,1989; Wilson 1987, 1996). An empirical literature has developed to evaluate the effect of spatial mismatch on the labor market outcomes of minorities (Holzer 1991; Kain 1992; Wheeler 1993; Ihlanfeldt and Sjoquist 1998) and low-skilled workers (Ong and Blumenberg 1998; Immergluck 1998; Ihlanfeldt 2006). Gobillon and Selod (2007) explain that workers may refuse a job that is far from where they live because of transportation costs, work inefficiency, and a decrease in job searching intensity. From the labor demand side, employers may discriminate against residentially segmented workers.

Our study finds that relocation might benefit the first generation through alleviating the spatial mismatch between job opportunities and residence. Resettlement might also make the second generation (children) stick to the destination place, where they tend to accumulate skills in the destination's pillar industry but are later negatively affected by industrial restructuring. Resettled children might be less likely to move to other locations for better job opportunities because of path dependence in work and residence after settling in the relocation destination.

The paper is organized as follows. Section 2 describes the background. Section 3 documents the data collection and reports the balance tests and summary statistics. Section 4 presents the empirical methodology and results. Section 5 concludes.

\section{Background and hypotheses}

\subsection{The poverty alleviation resettlement experiment}

Boshan is one of five districts in Zibo prefecture, which is located in the middle of Shandong province. Boshan has a complex geographic terrain in which $49.1 \%$ of the total area is mountainous. Before resettlement in 1994, villagers in the mountainous area earned less than half of the average in the whole district, 864 versus 1,780 Chinese yuan. ${ }^{6}$ People in the rural area have difficulty finding a job. Figure A-1 in the Appendix

\footnotetext{
${ }^{6}$ The current exchange rate between the Chinese yuan and the US dollar is around 1:7. The national annual average income in 1994 was 4,463 yuan (\$513) (National Bureau of Statistics of China 2020).
} 
displays the average annual income per capita for both migrant villages and host villages. $^{7}$

In the mountainous area of Boshan the cultivated farmland per capita is only 685 square meters, which is far less than the national average of 1,453 square meters per capita. Figure A-2 in the Appendix displays the average cultivated farmland in the migrant villages and comparison with the national average. Motivated by reducing the income disparities in Boshan district, in 1994 local government initiated a poverty alleviation experiment. Nineteen villages in the rural mountainous area were selected for resettlement. The resettlement started in June 1994 and it took several months for families to relocate to the suburban area near the urban core of Boshan. In total, 3,136 people from 19 villages were targeted for relocation.

The Boshan PAR was a voluntary experiment that gave the villagers the choice of whether or not to move. If they chose to relocate the government provided transportation support and helped them find transitional accommodation in the acceptance villages. Furthermore, after relocation the government offered them job training and provided them with new job opportunities, such as working in a nearby collective enterprise. If they chose to stay in their villages they were free to continue living in their old homes. However, the migrant villages and the host villages were merged and the people in the migrant villages were provided with the same hukou as those living in the host villages, regardless of their moving choice. According to statistics from the Boshan government, 2,414 individuals relocated to host villages, around $77 \%$ of the targeted group. The population distribution of the relocation is presented in Appendix Figure A-3.

\subsection{Hypotheses regarding the impact of PAR}

Relocation to an area with better public resources might raise children's school outcomes. Recent studies on the Moving To Opportunity (MTO) experiment and Public Housing Demolition program find that a modest improvement in school quality can be associated with substantial improvement in children's educational achievement when moving to an area with better school quality, though the impact varies with gender and the moving age (Chetty et al 2016b; Kling, Ludwig, and Katz 2005).

For the Boshan resettlement program, parents (the 'first generation') left their farmland and moved to suburban areas, changing from working in farms to working in factories in collective enterprises. We expect such a resettlement to greatly decease the probability of children being left behind and to increase their family income. With improved economic conditions, parents will support their children continuing further

\footnotetext{
${ }^{7}$ Altogether there were 19 migrant villages and 19 host villages.
} 
education. On the other hand, relocation might create a disruption cost for the children, who move to a new environment and face new neighbors and new teachers and students and may have difficulty integrating into the new community. Recent studies find a short-term negative impact of relocation on children's school achievement associated with the disruption cost. The negative impact is exacerbated when the resettlement is involuntary (Ingersoll, Scamman, and Eckerling 1989; Alexander, Entwisle, and Dauber 1994).

Another channel through which resettlement might affect children's education outcomes is employment and job opportunities. The PAR program provides migrants with more job opportunities. Before resettlement the families have few choices and most parents let the children stay in school until they are old enough to find a job outside the village. Because they live in a mountainous rural area, where they live is far from where they work. For safety reasons children, especially girls, are not allowed to work in the city when they are still young. In addition, education is compulsory for nine years without paying tuition fees, meaning children are more likely to stay in school for longer. The resettlement brings new opportunities for the families. They relocate to suburban areas where there are many collective enterprises. Therefore, in the resettled villages finding a job close to home is easier. In addition, the resettled families have lower incomes and less social connections than other households in the host village. If the expected return from children's further education is low, then parents will prefer that children find a job soon after the 9-year compulsory education has ended rather than continuing to study, or even that they drop out of school after resettlement.

There might be gender differences after resettlement. Son preference is a prominent phenomenon in rural China and other developing countries. More educational resources are given to boys since they are viewed as future breadwinners for their own families and supporters of their aging parents (Lambert and Rossi 2016). Once a girl gets married she might lose her connection with her family: In cultures where marriage means that a daughter becomes part of her husband's family, the incentive to educate girls is weaker. Therefore, most rural parents in developing countries want girls to find a job as early as possible and to contribute to the family before her marriage (Kumar 2013). Resettlement improves job access and induces parents to have girls work in the nearby collective enterprises when they are young, instead of continuing to study.

Although the relocated households are free to choose whether or not to move, they are not allowed to select their destination, which is similar to forced migration. Literature on forced migration reveals a mixed impact on migrants. Generally, study of forced migration in WWII suggests that the long-term impact on the migrants is often positive, while forced migration in developing countries tends to worsen labor market outcomes (Ruiz and Vargas-Silva 2013). Some studies also find that due to the 
'allocation rule', forced migration results in some misallocation of resources (Falck, Heblich, and Link 2011). Further, Bauer, Braun, and Kvasnicka (2012) find that both first and second generations of forced migrants have significantly lower-than-average incomes.

The 'one-to-one'-type PAR experiment can create a 'spatial mismatch' between the migrants' accumulated location-specific skills and the different level of economic development in the destination location. Generally, under the PAR experiment, government only offers financial support to migrants resettling in the designated host village. Financial subsidy might distort incentives and cause a skill mismatch for both first and second generations, leading to a negative impact on human capital.

To summarize, these multiple factors may trigger uncertain impacts on children's development after resettlement. The overall impact could be either positive or negative. In the empirical section we will explore the impacts of the Boshan resettlement on children's development in various dimensions.

\section{Data}

\subsection{Sample selection and data collection}

The field survey was conducted in January and February of 2019 with support from the local government in Boshan district. We first interviewed the government officials that designed the original resettlement program to learn about the whole decision process and implementation of the program. We also obtained all the original government documents and village-level data collected by the government before the resettlement in 1994. Government archives keep all records of social and economic information on both the treatment and control villages, including income per capita, different types of land area, demographics, etc.

The second step of our survey was to interview households. Our interview target was 200 households, based on the power analysis shown in Appendix A. The required sample size is 150 for a power analysis with $10 \%$ significance and 0.8 power level based on a two-sample means test. Eventually, we interviewed 179 households, 108 from the treatment villages and 71 from the control villages. ${ }^{8}$

We are interested in those children who were born before the resettlement and were less than 20 years old at the time of the resettlement. Therefore, the youngest person in our sample was at least 24 years old in 2018. The treatment group sample consists of children from the 19 resettled villages (children in the destination or host

\footnotetext{
${ }^{8}$ More discussion on power analysis is in Appendix A.
} 
villages do not belong to the treatment since they were not resettled). There are 17 control villages that are comparable to the resettled villages in the PAR program.

The household survey procedure was as follows: Local officers from the AntiPoverty Bureau of Boshan District took us to the villages and arranged a meeting with the village heads or a member of the village committee. The village leaders then helped us to contact the villagers for an interview. When conducting the interview we recorded the data using an online survey platform (Wen Juan Xing). A face-to-face interview was conducted with children currently living in the Boshan area. The interview was conducted intentionally during the national holiday period of the Chinese Spring Festival when many children return to Boshan to visit their parents, increasing the possibility of conducting face-to-face interviews and establishing connections with the interviewees. Online surveys were sent via Wechat to those working and living in suburban areas of or other cities. ${ }^{9}$

The relocated villages in the Boshan PAR experiment were not randomly assigned: The local government selected the smaller villages to make merging villages easier. ${ }^{10}$ Both control and treatment villages are located in the mountainous area, and local government conducted a systematic survey of both the treatment and control villages before the resettlement. The economic and social information in the government archives on those villages shows that both treatment and control villages had similar economic (income and land per capita) and geographical conditions. In the following empirical analysis, balance tests will be performed to test differences between the control and treatment villages at the individual level before the resettlement.

One data limitation is that individual information before 1994 and other variables before 2019 were collected retrospectively. To alleviate this problem, we designed the survey to collect information on school performance and household income in 1994 in ranking categories (high, medium, low) rather than the exact ranking number. Village information from the government archives was used as a robustness check. More details on the collection procedure and data accuracy are reported in Appendix B.

\subsection{Balance tests}

We conducted a balance test on the comparability of children in the control and treatment groups, since the experimented villages were not randomly assigned. Table 1 reports the results of the balance test for a set of variables prior to the 1994 resettlement across gender. There are no salient differences for most variables. For the whole (boys

\footnotetext{
${ }^{9}$ Most of the parents currently live in the Boshan area.

${ }^{10}$ If the migrant village had a larger population than the host village there would be increased pressure on the host village to provide financial support and public resources.
} 
and girls together) sample, one notable difference is that children in the control group are likely to be in a family with worse (self-evaluated) economic conditions than their neighbors in the village. This does not mean families in the treatment group are economically better off, since there was no salient difference between the control and treatment groups in parental income in 1994. Therefore, the difference in self-evaluated economic condition is possibly driven by perceived bias toward the rank of his/her family conditions in the control villages.

\subsection{Data description and summary statistics}

We investigate the impact on children's development from a life course perspective measured in four dimensions: education, income and employment, marriage and fertility, and living environment in adulthood. Table 2 provides the summary statistics for key outcomes across gender. Column (1) is the compliance rate - the ratio of actual resettlement. Columns (2) and (3) compare the average values of the experiment and control groups using a pooled sample. Columns (4) and (5) show the comparison for boys and columns (6) and (7) the comparison for girls. 
Table 1: Balance tests

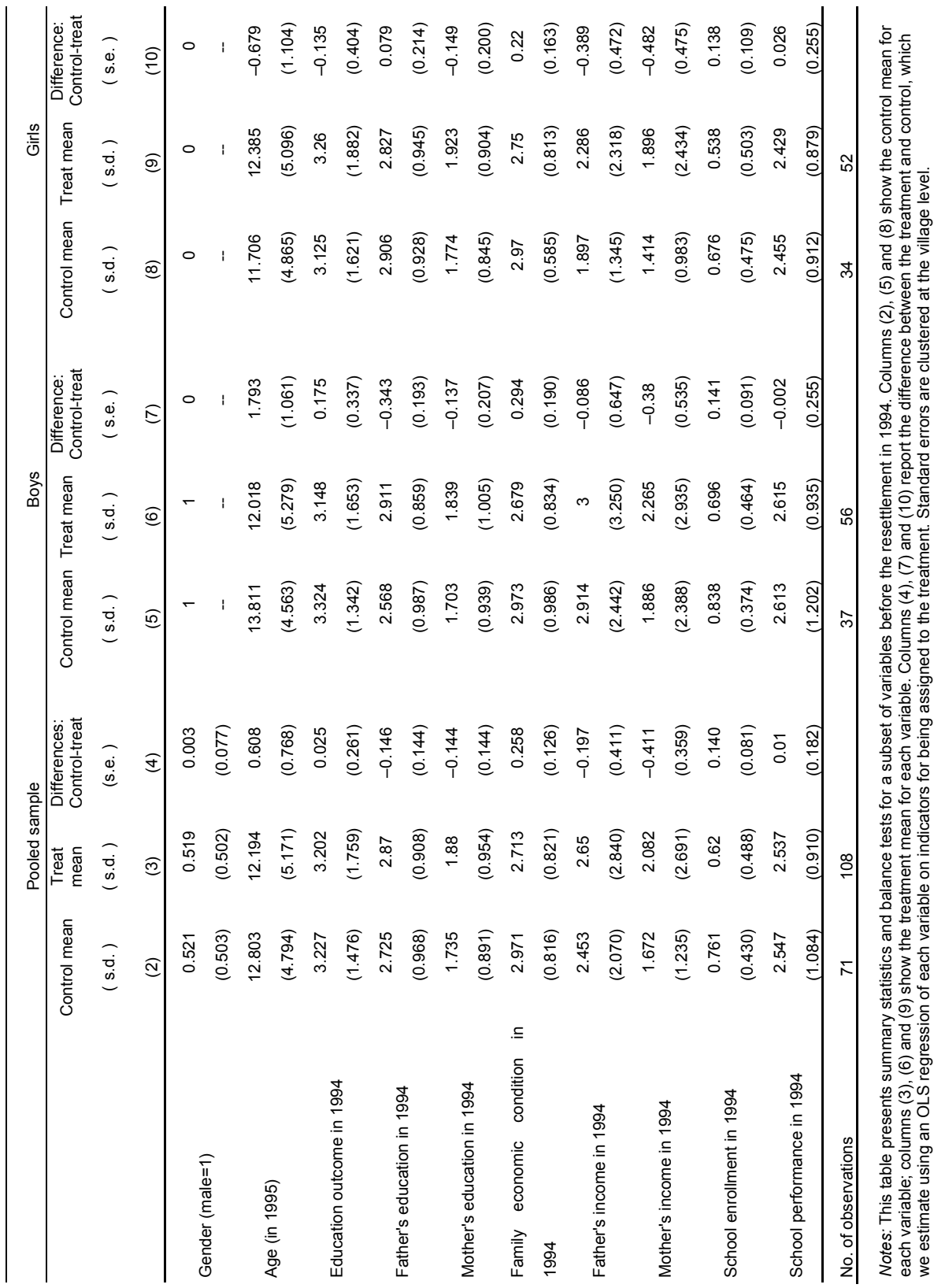


Zhan, Zhang \& Lu: Long-run effects of poverty alleviation resettlement on child development

Table 2: $\quad$ Summary statistics of dependent variables

\begin{tabular}{|c|c|c|c|c|c|c|}
\hline & \multicolumn{2}{|c|}{ Pooled sample } & \multicolumn{2}{|c|}{ Boys } & \multicolumn{2}{|c|}{ Girls } \\
\hline & Experiment & Control & Experiment & Control & Experiment & Control \\
\hline & Mean & $\begin{array}{l}\text { Mean } \\
\text { (s.d.) }\end{array}$ & $\begin{array}{l}\text { Mean } \\
\text { (s.d.) }\end{array}$ & $\begin{array}{l}\text { Mean } \\
\text { (s.d.) }\end{array}$ & $\begin{array}{l}\text { Mean } \\
\text { (s.d.) }\end{array}$ & $\begin{array}{l}\text { Mean } \\
\text { (s.d.) }\end{array}$ \\
\hline & $(2)$ & (3) & $(4)$ & & $(6)$ & \\
\hline PAR compliance $($ compliance $=1$ ) & $\begin{array}{r}0.778 \\
(0.417)\end{array}$ & 0 & $\begin{array}{c}0.732 \\
(0.447)\end{array}$ & 0 & $\begin{array}{c}0.827 \\
(0.382)\end{array}$ & 0 \\
\hline Education & & & & & & \\
\hline GPA ranking in class in 1995 & $\begin{array}{r}2.769 \\
(0.948)\end{array}$ & $\begin{array}{c}2.654 \\
(1.042)\end{array}$ & $\begin{array}{c}2.684 \\
(1.042)\end{array}$ & $\begin{array}{r}2.766 \\
(1.194)\end{array}$ & $\begin{array}{l}2.889 \\
(0.8)\end{array}$ & $\begin{array}{c}2.5 \\
(0.802)\end{array}$ \\
\hline $\begin{array}{l}\text { High School Entrance Exam } \\
\text { Participation (Participate = 1) }\end{array}$ & $\begin{array}{l}0.556 \\
(0.5)\end{array}$ & $\begin{array}{c}0.647 \\
(0.482)\end{array}$ & $\begin{array}{c}0.631 \\
(0.488)\end{array}$ & $\begin{array}{l}0.667 \\
(0.48)\end{array}$ & $\begin{array}{c}0.471 \\
(0.506)\end{array}$ & $\begin{array}{r}0.625 \\
(0.494)\end{array}$ \\
\hline $\begin{array}{l}\text { Scores in High School Entrance Exam } \\
(\text { Top }=20 \%, \ldots \text { Lowest } 20 \%)\end{array}$ & $\begin{array}{r}2.975 \\
(0.946)\end{array}$ & $\begin{array}{r}2.909 \\
(1.071)\end{array}$ & $\begin{array}{l}3.125 \\
(0.85)\end{array}$ & $\begin{array}{c}3 \\
(1.137)\end{array}$ & $\begin{array}{c}2.75 \\
(1.064)\end{array}$ & $\begin{array}{c}2.78 \\
(1.014)\end{array}$ \\
\hline $\begin{array}{l}\text { High school/Technical school enrollment } \\
(\text { enroll = 1) }\end{array}$ & $\begin{array}{r}0.408 \\
(0.495)\end{array}$ & $\begin{array}{c}0.542 \\
(0.503)\end{array}$ & $\begin{array}{r}0.459 \\
(0.505)\end{array}$ & $\begin{array}{r}0.538 \\
(0.508)\end{array}$ & $\begin{array}{r}0.323 \\
(0.485)\end{array}$ & $\begin{array}{r}0.545 \\
(0.509)\end{array}$ \\
\hline School dropout rate $($ dropout $=1)$ & $\begin{array}{c}0.157 \\
(0.366)\end{array}$ & $\begin{array}{r}0.119 \\
(0.326)\end{array}$ & $\begin{array}{c}0.111 \\
(0.318)\end{array}$ & $\begin{array}{l}0.097 \\
(0.3)\end{array}$ & $\begin{array}{c}0.211 \\
(0.413)\end{array}$ & $\begin{array}{r}0.143 \\
(0.356)\end{array}$ \\
\hline Income and job selection & & & & & & \\
\hline Individual income in 2018 & $\begin{array}{r}3.168 \\
(1.784)\end{array}$ & $\begin{array}{c}3.821 \\
(2.181)\end{array}$ & $\begin{array}{r}3.796 \\
(1.852)\end{array}$ & $\begin{array}{c}4.444 \\
(2.083)\end{array}$ & $\begin{array}{c}2.446 \\
(1.742)\end{array}$ & $\begin{array}{c}3.097 \\
(1.972)\end{array}$ \\
\hline Individual income in 2016 & $\begin{array}{c}2.832 \\
(1.217)\end{array}$ & $\begin{array}{r}3.418 \\
(1.884)\end{array}$ & $\begin{array}{c}3.167 \\
(1.194)\end{array}$ & $\begin{array}{r}3.639 \\
(1.743)\end{array}$ & $\begin{array}{c}2.447 \\
(1.138)\end{array}$ & $\begin{array}{c}3.161 \\
(2.035)\end{array}$ \\
\hline Individual income in 2014 & $\begin{array}{r}2.426 \\
(1.099)\end{array}$ & $\begin{array}{r}3.045 \\
(1.727)\end{array}$ & $\begin{array}{c}2.741 \\
(1.119)\end{array}$ & $\begin{array}{c}3.306 \\
(1.818)\end{array}$ & $\begin{array}{c}2.064 \\
(0.965)\end{array}$ & $\begin{array}{r}2.742 \\
(1.591)\end{array}$ \\
\hline Household entrepreneur (yes $=1$ ) & $\begin{array}{c}0.148 \\
(0.357)\end{array}$ & $\begin{array}{r}0.183 \\
(0.389)\end{array}$ & $\begin{array}{c}0.196 \\
(0.401)\end{array}$ & $\begin{array}{r}0.243 \\
(0.435)\end{array}$ & $\begin{array}{c}0.096 \\
(0.298)\end{array}$ & $\begin{array}{r}0.118 \\
(0.327)\end{array}$ \\
\hline Farm work (yes = 1) & $\begin{array}{c}0.037 \\
(0.19)\end{array}$ & $\begin{array}{c}0.07 \\
(0.258)\end{array}$ & $\begin{array}{r}0.036 \\
(0.187)\end{array}$ & $\begin{array}{c}0.054 \\
(0.229)\end{array}$ & $\begin{array}{c}0.038 \\
(0.194)\end{array}$ & $\begin{array}{r}0.088 \\
(0.288)\end{array}$ \\
\hline $\begin{array}{l}\text { Large-scale enterprises or institutions } \\
(Y e s=1)\end{array}$ & $\begin{array}{c}0.102 \\
(0.304)\end{array}$ & $\begin{array}{c}0.225 \\
(0.421)\end{array}$ & $\begin{array}{c}0.107 \\
(0.312)\end{array}$ & $\begin{array}{c}0.27 \\
(0.45)\end{array}$ & $\begin{array}{c}0.096 \\
(0.298)\end{array}$ & $\begin{array}{r}0.176 \\
(0.387)\end{array}$ \\
\hline Marriage and fertility & & & & & & \\
\hline Marriage rate $($ Marriage $=1$, others $=0$ ) & $\begin{array}{c}0.861 \\
(0.347)\end{array}$ & $\begin{array}{r}0.859 \\
(0.350)\end{array}$ & $\begin{array}{r}0.875 \\
(0.333)\end{array}$ & $\begin{array}{c}0.918 \\
(0.276)\end{array}$ & $\begin{array}{r}0.846 \\
(0.64)\end{array}$ & $\begin{array}{r}0.794 \\
(0.410)\end{array}$ \\
\hline Divorce rate $($ Divorce $=1$, others $=0$ ) & $\begin{array}{c}0.028 \\
(0.165)\end{array}$ & $\begin{array}{c}0.070 \\
(0.258)\end{array}$ & $\begin{array}{r}0.018 \\
(0.133)\end{array}$ & $\begin{array}{c}0.054 \\
(0.229)\end{array}$ & $\begin{array}{c}0.038 \\
(0.194)\end{array}$ & $\begin{array}{r}0.088 \\
(0.288)\end{array}$ \\
\hline Fertility age (for female children only) & - & - & - & - & $\begin{array}{l}25.442 \\
(3.179)\end{array}$ & $\begin{array}{r}26.461 \\
(2.83)\end{array}$ \\
\hline Living environment & & & & & & \\
\hline $\begin{array}{l}\text { Hukou type (non-agricultural hukou }=1 \text {, } \\
\text { agricultural hukou }=0 \text { ) }\end{array}$ & $\begin{array}{c}0.241 \\
(0.271)\end{array}$ & $\begin{array}{c}0.282 \\
(0453)\end{array}$ & $\begin{array}{c}0.303 \\
(0.463)\end{array}$ & $\begin{array}{c}0.270 \\
(0.450)\end{array}$ & $\begin{array}{c}0.173 \\
(0.382)\end{array}$ & $\begin{array}{c}0.294 \\
(0.462)\end{array}$ \\
\hline Housing value (thousand yuan) & $\begin{array}{r}324.89 \\
(297.55)\end{array}$ & $\begin{array}{r}485.38 \\
(376.13)\end{array}$ & $\begin{array}{c}328.38 \\
(426.02)\end{array}$ & $\begin{array}{r}463.75 \\
(370.08)\end{array}$ & $\begin{array}{c}321.06 \\
(349.65)\end{array}$ & $\begin{array}{c}520.00 \\
(396.12)\end{array}$ \\
\hline $\begin{array}{l}\text { City ranking (the most developed cities } \\
=1 \text {, the rest }=0 \text { ) }\end{array}$ & $\begin{array}{c}0.046 \\
(0.211)\end{array}$ & $\begin{array}{r}0.056 \\
(0.232)\end{array}$ & $\begin{array}{r}0.036 \\
(0.187)\end{array}$ & $\begin{array}{c}0.054 \\
(0.229)\end{array}$ & $\begin{array}{c}0.058 \\
(0.235)\end{array}$ & $\begin{array}{r}0.058 \\
(0.238)\end{array}$ \\
\hline
\end{tabular}

\subsubsection{Education outcome}

Education outcome is measured by GPA ranking in class after resettlement in 1995 according to a self-reported five-item Likert scale: top/excellent, above average, average, below average, and bottom. The long-term education outcomes are evaluated 
using participation rate and performance in the high school entrance exam, actual attendance in high school/technical school, the quality of high school enrolled in, college attendance, and school dropout rate.

In China, primary and middle school education is compulsory, ${ }^{11}$ lasts 9 years, ${ }^{12}$ and is free. For children studying in high school after the 9-year compulsory education there is a tuition fee. After children finish middle school education, students and their parents decide whether to continue with a high school education or go to work.

Participation in the high school entrance exam is a binary choice variable on whether the child takes the exam or not $(\mathrm{Yes}=1, \mathrm{No}=0)$. The treatment group has a lower participation rate than the control group, especially for girls. The scores in the high school entrance exam are measured using a self-reported five-item Likert scale. High/Technical school enrollment is a dummy variable with a base group " 0 " for not being enrolled in any high school.

\subsubsection{Income and employment in adulthood}

Individual income in 2014, 2016, and 2018 is self-reported. Income is the sum of wage earnings, self-employed income, and other income, before tax. It is measured in low-to high-income brackets using a category variable, with category values from 1 (below $1,000 /$ month) to 11 (above 50,000/month). In addition, we asked for information on occupation choice and employment status, including nonfarm employment, starting up a business, or migrating to large cities for better job opportunities.

We examine three forms of employment: entrepreneurship, farm work, and largescale enterprise/institution. Entrepreneurship is an indicator of starting one's own business. Farm work is an indicator of both full-time farm work and farm work accompanied by temporary jobs. Large-scale enterprise/institution refers to more stable jobs with decent remuneration, such as in state-owned enterprises and public institutions. Working in such an organization is an indicator variable.

\footnotetext{
${ }^{11}$ Since the promulgation of the Compulsory Education Law of the People's Republic of China in 1986, nineyear compulsory education has been implemented by various levels of government.

${ }_{12}$ Primary school education lasts either five (35\% of enrollment) or six ( $65 \%$ of enrollment) years depending on region. Most junior high school students take three years of schooling ( $98 \%$ of enrollment), and only a small fraction takes four years.
} 


\subsubsection{Marriage and fertility}

We use marriage and divorce rate to evaluate marriage stability in adulthood. Marriage status has four categories: married, divorced, single, and widow/widower. Table 2 shows that the treatment and control groups tend to have similar marriage rates, while the average divorce rate in the treatment group $(2.8 \%)$ is lower than the control mean (7\%). Female children in the treatment group tend to have their first child at an average age of 25.44, which is slightly earlier than the control group mean (26.45).

\subsubsection{Living environment}

Three indicators are employed to evaluate the living environment: the child's current hukou registration status, the rank of the city where the child currently lives, and the value of the housing unit owned by the child. Within the Chinese hukou system a person with non-agricultural hukou generally lives in an urban area and is able to obtain more/better quality public resources. A child usually has the same hukou type as his/her parents. ${ }^{13}$ Whether a migrant has urban hukou is an important indicator of welfare. Housing value affects family welfare through the following channels: it is a major component of household assets and has the potential to greatly appreciate during China's housing boom, and it is an important indicator of the family's living environment and affects children's access to good quality schools. To rank the cities we adopt the widely acknowledged Yi-Magazine's China City Ranking, based on five indices: business density, geographic location and transportation development, life-style diversity, innovation, and the city's potential development. Based on these five indices, Chinese cities are classified into six categories, ranking from first-tier and new first-tier to fifth-tier cities. ${ }^{14}$ In this study the more developed first three city tiers are coded as "1".

Using a pooled sample, Table 2 shows that $24.1 \%$ of the children in the treatment group have non-agricultural hukou, which is lower than the control means $(28.2 \%)$. In addition, in 2018 the average housing value for the treatment group (424.89 thousand yuan) is lower than the control mean (485.38 thousand yuan). The fraction in the treatment group living in more developed cities is $4.6 \%$, less than that of the control group $(5.6 \%)$.

\footnotetext{
${ }^{13}$ If the second generation has a non-agricultural hukou their child (the third generation) generally has the same type of hukou. For more detailed introduction on hukou reform in recent years see Zhang, Wang, and Lu (2019).

${ }^{14}$ Zibo is classified as a third-tier city.
} 


\section{Empirical methodology and results}

The empirical analysis follows an approach commonly used for evaluating the effect of relocation on individual outcomes (Kling et al. 2007; Chetty et al. 2016). We first estimate intent to treat (ITT) effects on an outcome $(y)$, specified as:

$$
y_{i}=\alpha+\beta^{I T T} A_{s s i g n}+\gamma X_{i}+\varepsilon_{i}
$$

where Assign is an indicator variable for being assigned to the treatment group and $X$ is a vector of baseline covariates before resettlement, including parents' income and education, children's education and age, and rank of the family's economic situation. Standard errors are clustered at village level to allow for common error components across villages because the resettlement occurred at the village level. In the benchmark specification we do not include additional $X$ covariates. As a robustness check we estimate models with covariates included, which change the point estimates but not the direction of coefficients.

The ITT estimates might understate the causal effect of actual relocations since not all households assigned to the treatment group actually moved. We next estimate the effect of treatment-on-treated (TOT) using the following specification:

$$
y_{i}=\alpha+\beta^{T o T} \text { Relocate }_{i}+\gamma X_{i}+\varepsilon_{i} .
$$

The endogeneity problem comes from self-selection: families in the treatment group can choose to not move to the host village. Hence, we estimate the TOT effect using the assigned allocation (Assign) as an instrumental variable for actual relocation (Relocate) employing two-stage least squares estimation (2SLS). The validity of the instrumental variable (IV) has two requirements. One is that assignment treatment affects actual relocation, which is true as documented in Section A below. The other is the exclusion restriction that requires: (1) that the treatment assignment is not an individual household choice, which is true since the PAR program is designed by the government; and (2) that the assignment itself has no other channels that affect children's current outcome other than its relocation impact, which is reasonable since the villages were comparable at the time of resettlement. The software STATA 14 is used for the empirical analysis.

The following sections first present the compliance rate for household relocation, followed by children's education achievement, income and career selection, marriage and fertility, and living environment in adulthood. We report both ITT and TOT results without control variables in the main text and additional results in the Appendix. 


\subsection{Compliance rate and educational outcomes}

Table 3 shows the compliance rate of the Boshan relocation program and its short-term impact on education. Panels A, B, and C show the pooled sample, male children, and female children respectively. Column (1) of Table 3 reports estimates with an indicator for actual relocation as the dependent variable. The control group mean is zero for this outcome because those in the control group did not relocate. The estimated compliance rates for families with boys are lower than for those with girls, $79 \%$ versus $84 \%$.

Table 3: Compliance rate of moving under the Boshan PAR program and short-run impact on education performance

\begin{tabular}{lccc}
\hline & Compliance rate & \multicolumn{2}{c}{ Short-term education performance } \\
\cline { 2 - 4 } & ITT & ITT & TOT \\
\cline { 2 - 4 } & $(1)$ & $(2)$ & $(3)$ \\
\cline { 2 - 4 } Panel A: Pooled sample & & 0.105 & 0.128 \\
Exp. vs. control & 0.813 & $(0.177)$ & $(0.216)$ \\
Observations & $(0.068)$ & 117 & 117 \\
Control means & 179 & 2.654 & 2.654 \\
Panel B: Boys & 0 & & -0.272 \\
Exp. vs. control & & -0.222 & $(0.394)$ \\
& 0.792 & $(0.333)$ & 68 \\
Observations & $(0.075)$ & 68 & 2.767 \\
Control means & 93 & 2.767 & 0.662 \\
Panel C: Girls & 0 & & $(0.380)$ \\
Exp. vs. control & & 0.498 & 49 \\
Observations & 0.837 & $(0.273)$ & 2.5 \\
Control means & $(0.086)$ & 49 & 2.5 \\
\hline
\end{tabular}

Notes: Z-scores are calculated by subtracting the control group mean and dividing by the control group standard deviation. The higher the score (negatively related to GPA in raw data), the worse the performance. Samples are restricted to children who enrolled in school in 1994. Standard errors, reported in parentheses, are clustered by village. For all the specifications, the regional indicators are included.

The short-term impact on children's school performance is measured by their GPA ranking in their class one year after the resettlement. Z-scores are calculated by subtracting the control group mean and dividing by the control group standard deviation. The higher the score (negatively related to GPA), the worse the performance. We restrict the sample to children enrolled in school prior to the resettlement. Columns (2) and (3) report the ITT and TOT estimates of children's school performance without control variables included. Estimation using pooled data shows that the relocation has a positive impact on students' short-term educational outcome.

There is a salient gender difference, with girls appearing to suffer from the move to new places, while for boys it has a positive impact. The ITT (TOT) benchmark estimation for girls has an effect size of 0.498 (0.610) standard deviation from the 
control mean, implying that girls' self-reported GPA ranking decreased one year after resettlement compared with the control mean. It implies that girls may take more time to adjust to the new school and neighborhood environment.

After the nine years of compulsory education, taking the high school entrance exam and entering high school for further study are important indicators of better education, so we investigate whether the Boshan PAR experiment improved performance in the high school entrance exam and children's high school enrollment.

Panel A and Panel B in Table 4 report estimates of the high school entrance exam participation rate and the high school attendance rate. Our benchmark ITT estimation shows that resettlement decreases the participation rate in the high school entrance exam by $14 \%$ for the whole sample. Girls in the treatment group are $19.2 \%$ less likely to take the entrance exam and $14 \%$ less likely to attend high school. For boys the difference between the treatment group and the control group in the benchmark ITT specification is small.

Panel C of Table 4 shows whether the PAR experiment improved children's performance in the high school entrance exam, based on their score ranking in the entrance exam and the quality of the high school they enrolled in. We restrict our sample to children who took the entrance exam and know their scores (110 observations). No difference is discovered between control and treatment group.

Panel D in Table 4 reports the results on school dropout. The impact is heterogeneous across gender: there is no impact on boys, while the girls in the treatment group have an $8.7 \%$ higher dropout rate than the control group in the benchmark estimation. 
Zhan, Zhang \& Lu: Long-run effects of poverty alleviation resettlement on child development

Table 4: Continuation of education after nine-year compulsory schooling

\begin{tabular}{|c|c|c|c|c|c|c|}
\hline & \multicolumn{2}{|c|}{ Pooled Sample } & \multicolumn{2}{|c|}{ Boys } & \multicolumn{2}{|c|}{ Girls } \\
\hline & ITT & TOT & ITT & TOT & ITT & TOT \\
\hline & $(1)$ & $(2)$ & (3) & (4) & $(5)$ & (6) \\
\hline \multicolumn{7}{|c|}{ Panel A: High school entrance exam participation rate $(Y e s=1 ;$ No $=0)$} \\
\hline \multirow[t]{2}{*}{ Exp. vs. control } & -0.14 & -0.178 & -0.145 & -0.196 & -0.137 & -0.166 \\
\hline & $(0.076)$ & $(0.098)$ & $(0.138)$ & $(0.176)$ & $(0.088)$ & $(0.099)$ \\
\hline Observations & 179 & 179 & 95 & 95 & 78 & 78 \\
\hline Control mean & 0.647 & 0.647 & 0.667 & 0.667 & 0.625 & 0.625 \\
\hline \multicolumn{7}{|c|}{ Panel B: High school attendance rate $(Y e s=1, N=0)$} \\
\hline \multirow[t]{2}{*}{ Exp. vs. control } & -0.094 & -0.121 & -0.05 & -0.068 & -0.14 & -0.169 \\
\hline & $(0.074)$ & $(0.095)$ & $(0.117)$ & $(0.157)$ & $(0.074)$ & $(0.099)$ \\
\hline Observations & 172 & 172 & 89 & 89 & 83 & 83 \\
\hline Control mean & 0.454 & 0.454 & 0.441 & 0.441 & 0.468 & 0.468 \\
\hline \multicolumn{7}{|c|}{ Panel C: Ranking in high school entrance exam (Z-score) } \\
\hline \multirow[t]{2}{*}{ Exp. vs. control } & 0.063 & 0.065 & 0.026 & 0.025 & 0.045 & 0.047 \\
\hline & $(0.196)$ & $(0.201)$ & $(0.38)$ & $(0.038)$ & $(0.391)$ & $(0.4)$ \\
\hline Observations & 110 & 110 & 61 & 61 & 49 & 49 \\
\hline Control mean & 2.909 & 2.909 & 3 & 3 & 2.8 & 2.8 \\
\hline \multicolumn{7}{|c|}{ Panel D: School dropout rate } \\
\hline \multirow[t]{2}{*}{ Exp. vs. control } & 0.062 & 0.078 & 0.065 & 0.088 & 0.087 & 0.099 \\
\hline & $(0.057)$ & $(0.073)$ & $(0.061)$ & $(0.075)$ & $(0.046)$ & $(0.114)$ \\
\hline Observations & 179 & 179 & 93 & 93 & 86 & 86 \\
\hline Control mean & 0.113 & 0.113 & 0.081 & 0.081 & 0.147 & 0.147 \\
\hline
\end{tabular}

Notes: The dependent variable in panel $\mathrm{A}$ is an indicator of participation in the high school entrance exam. The dependent variable in panel $\mathrm{B}$ is an indicator of high/technical school attendance rate. The dependent variable in Panel $\mathrm{C}$ is a categorical variable of selfranking of scores in the high school entrance exam, and Panel $\mathrm{C}$ restricts samples to children who have scores in the entrance exam. The dependent variable in panel $\mathrm{D}$ is the school dropout rate. Regional indicator is included. Standard errors in parentheses are clustered at village level.

\subsection{Income and occupation choice in adulthood}

\subsubsection{Income in adulthood}

Table 5 presents the impact of resettlement on children's income and employment in adulthood. Columns (1) and (2) report the results using a pooled sample, columns (3) and (4) report estimates for boys, and columns (5) and (6) show estimates for girls. Panels A, B, and C in Table 5 present the estimates using children's income in 2018, 2016, and 2014, respectively. Panel D in Table 5 reports the estimates using children's 
5-year average individual income (2014, 2016, and 2018). Panel E provides a robustness check by taking the medium value of the categorical income bracket. ${ }^{15}$

Table 5: $\quad$ The impact of PAR on income

\begin{tabular}{|c|c|c|c|c|c|c|}
\hline & \multicolumn{2}{|c|}{ Pooled sample } & \multicolumn{2}{|c|}{ Boys } & \multicolumn{2}{|c|}{ Girls } \\
\hline & ITT & TOT & ITT & TOT & ITT & TOT \\
\hline & (1) & (2) & (3) & (4) & (5) & $(6)$ \\
\hline \multicolumn{7}{|c|}{ Panel A: Personal income in 2018} \\
\hline Exp. vs. control & $\begin{array}{r}-0.721 \\
(0.39)\end{array}$ & $\begin{array}{l}-0.94 \\
(0.513)\end{array}$ & $\begin{array}{c}-0.785 \\
(0.423)\end{array}$ & $\begin{array}{c}-1.078 \\
(0.574)\end{array}$ & $\begin{array}{c}-0.734 \\
(0.392)\end{array}$ & $\begin{array}{c}-0.734 \\
(0.392)\end{array}$ \\
\hline Observations & 179 & 179 & 90 & 90 & 78 & 78 \\
\hline Control mean & 3.821 & 3.821 & 4.444 & 4.444 & 3.097 & 3.097 \\
\hline \multicolumn{7}{|c|}{ Panel B: Personal income in 2016} \\
\hline Exp. vs. control & $\begin{array}{c}-0.671 \\
(0.259)\end{array}$ & $\begin{array}{c}-0.874 \\
(0.348)\end{array}$ & $\begin{array}{c}-0.592 \\
(0.247)\end{array}$ & $\begin{array}{c}-0.812 \\
(0.332)\end{array}$ & $\begin{array}{c}-0.789 \\
(0.385)\end{array}$ & $\begin{array}{c}-0.971 \\
(0.474)\end{array}$ \\
\hline Observations & 179 & 179 & 90 & 90 & 78 & 78 \\
\hline Control mean & 3.418 & 3.418 & 3.639 & 3.639 & 3.161 & 3.161 \\
\hline \multicolumn{7}{|c|}{ Panel C: Personal income in 2014} \\
\hline Exp. vs. control & $\begin{array}{c}-0.727 \\
(0.249)\end{array}$ & $\begin{array}{c}-0.947 \\
(0.323)\end{array}$ & $\begin{array}{c}-0.775 \\
(0.316)\end{array}$ & $\begin{array}{r}-1.064 \\
(0.404)\end{array}$ & $\begin{array}{c}-0.729 \\
(0.321)\end{array}$ & $\begin{array}{c}-0.896 \\
(0.386)\end{array}$ \\
\hline Observations & 179 & 179 & 90 & 90 & 78 & 78 \\
\hline Control mean & 3.045 & 3.045 & 3.306 & 3.306 & 2.742 & 2.742 \\
\hline \multicolumn{7}{|c|}{ Panel D: Average personal income $(2014,2016$, and 2018$)$} \\
\hline Exp. vs. control & $\begin{array}{r}-0.707 \\
(0.269)\end{array}$ & $\begin{array}{c}-0.92 \\
(0.359)\end{array}$ & $\begin{array}{c}-0.717 \\
(0.297)\end{array}$ & $\begin{array}{c}-0.984 \\
(0.397)\end{array}$ & $\begin{array}{c}-0.751 \\
(0.301)\end{array}$ & $\begin{array}{c}-0.923 \\
(0.381)\end{array}$ \\
\hline Observations & 179 & 179 & 90 & 90 & 78 & 78 \\
\hline Control mean & 3.428 & 3.428 & 3.796 & 3.796 & 3 & 3 \\
\hline \multicolumn{7}{|c|}{ Panel E: Average personal income (Chinese yuan) - robustness check } \\
\hline Exp. vs. control & $\begin{array}{r}-1385.4 \\
(624.9)\end{array}$ & $\begin{array}{r}-1804.7 \\
(819.9)\end{array}$ & $\begin{array}{c}-1676.8 \\
(829)\end{array}$ & $\begin{array}{l}-2300 \\
(11117)\end{array}$ & $\begin{array}{c}-1153.2 \\
(556)\end{array}$ & $\begin{array}{c}-1418.4 \\
(689)\end{array}$ \\
\hline Observations & 179 & 179 & 90 & 90 & 78 & 78 \\
\hline Control mean & 3595 & 3595 & 4162 & 4162 & 2935.5 & 2935.5 \\
\hline
\end{tabular}

Notes: Income information is collected by income bracket and is defined as a categorical variable from low to high (1 to 11); the exception is Panel $E$ where the dependent variable is income measured in Chinese yuan, taking the medium value of an income bracket. Personal income includes all wage income, self-employed income, social transfers, and investment income before tax. Standard errors, reported in parentheses, are clustered at the village level.

Using a pooled sample, both the ITT and TOT benchmark estimates show that relocation has a negative impact on children's income in adulthood. In our survey there are 11 income brackets. Taking the medium value of each income bracket, the benchmark ITT estimation shows that resettlement decreases children's income by 1,385 Chinese yuan for the treatment group compared with the control group mean of 3,595 Chinese yuan. Resettlement has a negative impact on adult income for both genders.

${ }^{15}$ For example, if a child's income is within the income bracket of 4,000-5,000 Chinese yuan per month we take the medium value of 4,500 as their monthly income. 
Using a category measure, the adult income of children in the treatment group decreases by 0.721 points (the mean is 3.82). The corresponding TOT effect for children whose families actually moved is a decrease of 0.94 points. Using three-year average income, resettlement leads to a drop of 0.707 points in adult income according to ITT estimation.

\subsubsection{Occupation choice}

Panel A in Table 6 reports the impact of relocation on family entrepreneurship. No difference is found in the treatment group regarding the selection of the household into being entrepreneurial, in both the pooled sample and across gender. Panel B in Table 6 shows whether relocation makes children less likely than their parents to continue in farm work or to seek other opportunities. No impact is discovered in the treatment group. The PAR experiment reduces children's probability of working in state-owned enterprises or government institutions by $13.6 \%(17.4 \%)$ in ITT (TOT) estimation.

\section{Table 6: The impact of PAR on job selection}

\begin{tabular}{|c|c|c|c|c|c|c|}
\hline & \multicolumn{2}{|c|}{ Pooled sample } & \multicolumn{2}{|c|}{ Boys } & \multicolumn{2}{|c|}{ Girls } \\
\hline & ITT & TOT & ITT & TOT & ITT & TOT \\
\hline & (1) & (2) & (3) & $(4)$ & (5) & (6) \\
\hline \multicolumn{7}{|c|}{ Panel A: Entrepreneurship (Yes $=1$, No $=0)$} \\
\hline Exp. vs. control & $\begin{array}{c}-0.037 \\
(0.052)\end{array}$ & $\begin{array}{c}-0.051 \\
(0.06)\end{array}$ & $\begin{array}{l}-0.05 \\
(0.081)\end{array}$ & $\begin{array}{l}-0.047 \\
(0.082)\end{array}$ & $\begin{array}{c}-0.032 \\
(0.067)\end{array}$ & $\begin{array}{c}-0.031 \\
(0.071)\end{array}$ \\
\hline Observations & 179 & 179 & 93 & 93 & 86 & 86 \\
\hline Control mean & 0.183 & 0.183 & 0.243 & 0.243 & 0.118 & 0.118 \\
\hline \multicolumn{7}{|c|}{ Panel B: Farm work (yes $=1$, No $=0$ ) } \\
\hline Exp. vs. control & $\begin{array}{c}-0.028 \\
(0.049)\end{array}$ & $\begin{array}{c}-0.036 \\
(0.061)\end{array}$ & $\begin{array}{c}-0.023 \\
(0.047)\end{array}$ & $\begin{array}{l}-0.02 \\
(0.044)\end{array}$ & $\begin{array}{l}-0.07 \\
(0.075)\end{array}$ & $\begin{array}{c}-0.071 \\
(0.077)\end{array}$ \\
\hline Observations & 179 & 179 & 93 & 93 & 86 & 86 \\
\hline Control mean & 0.07 & 0.07 & 0.054 & 0.054 & 0.088 & 0.088 \\
\hline \multicolumn{7}{|c|}{ Panel C: Publicly owned company/foreign-owned company $(y e s=1$, No $=0)$} \\
\hline Exp. vs. control & $\begin{array}{c}-0.136 \\
(0.074)\end{array}$ & $\begin{array}{c}-0.174 \\
(0.094)\end{array}$ & $\begin{array}{c}-0.201 \\
(0.132)\end{array}$ & $\begin{array}{l}-0.271 \\
(0.184)\end{array}$ & $\begin{array}{l}-0.077 \\
(0.065)\end{array}$ & $\begin{array}{c}-0.093 \\
(0.066)\end{array}$ \\
\hline Observations & 179 & 179 & 93 & 93 & 86 & 86 \\
\hline Control mean & 0.225 & 0.225 & 0.27 & 0.27 & 0.176 & 0.27 \\
\hline
\end{tabular}

Notes: The dependent variables in panels $\mathrm{A}, \mathrm{B}$, and $\mathrm{C}$ are indicators of starting up a business, being a farmer, and working in stateowned firms or public institutions, respectively. Standard errors, reported in parentheses, are clustered by village. 


\subsubsection{Marriage and fertility}

In Table 7, columns (1), (3), and (5) (columns (2), (4), and (6)) present the benchmark ITT (TOT) effects of resettlement on marriage and fertility. The dependent variable in panel A is an indicator of being married in 2018. The dependent variable in panel B is an indicator of being divorced in 2018. Panel $\mathrm{C}$ restricts the sample to females who have given birth; the dependent variable is age at first childbirth. Results from panel A and Panel B show no impact on children's marriage and divorce rate in adulthood for pooled or separate samples.

The benchmark estimation finds that resettlement decreases female children's fertility age by 0.95 years. This might be because after resettlement children in the treatment group tend to live in the host village with a relatively better/more stable life without the incentive to work out of town, and thus they tend to have children at earlier ages.

Table 7: The impact of PAR on marriage and fertility

\begin{tabular}{|c|c|c|c|c|c|c|}
\hline & \multicolumn{2}{|c|}{ Pooled sample } & \multicolumn{2}{|c|}{ Boys } & \multicolumn{2}{|c|}{ Girls } \\
\hline & ITT & TOT & ITT & TOT & ITT & TOT \\
\hline & $(1)$ & $(2)$ & (3) & (4) & (5) & (6) \\
\hline \multicolumn{7}{|c|}{ Panel A: Marriage (marriage $=1$, other $=0$ ) } \\
\hline Exp. vs. control & $\begin{array}{c}0.016 \\
(0.037)\end{array}$ & $\begin{array}{c}0.02 \\
(0.46)\end{array}$ & $\begin{array}{c}-0.02 \\
(0.43)\end{array}$ & $\begin{array}{c}-0.027 \\
(0.056)\end{array}$ & $\begin{array}{c}0.051 \\
(0.077)\end{array}$ & $\begin{array}{c}0.062 \\
(0.087)\end{array}$ \\
\hline Observations & 179 & 179 & 93 & 93 & 86 & 86 \\
\hline Control mean & 0.859 & 0.859 & 0.918 & 0.918 & 0.794 & 0.794 \\
\hline \multicolumn{7}{|c|}{ Panel B: Divorce (divorce $=1$, other $=0$ ) } \\
\hline Exp. vs. control & $\begin{array}{c}-0.044 \\
(0.04)\end{array}$ & $\begin{array}{c}-0.056 \\
(0.048)\end{array}$ & $\begin{array}{c}-0.046 \\
(0.036)\end{array}$ & $\begin{array}{c}-0.063 \\
(0.048)\end{array}$ & $\begin{array}{c}-0.043 \\
(0.052)\end{array}$ & $\begin{array}{c}-0.051 \\
(0.06)\end{array}$ \\
\hline Observations & 179 & 179 & 93 & 93 & 86 & 86 \\
\hline Control mean & 0.07 & 0.07 & 0.054 & 0.054 & 0.088 & 0.088 \\
\hline \multicolumn{7}{|c|}{ Panel C: First birth (in age) } \\
\hline \multirow[t]{2}{*}{ Exp. vs. control } & -- & -- & -- & -- & -0.948 & -1.156 \\
\hline & -- & -- & -- & -- & $(0.493)$ & $(0.66)$ \\
\hline Observations & -- & -- & -- & -- & 69 & 69 \\
\hline Control mean & -- & -- & -- & -- & 26.461 & 25.84 \\
\hline
\end{tabular}

Notes: The dependent variable in panel A is an indicator of being married in 2018. The dependent variable in panel B is an indicator of being divorced in 2018. Panel C restricts the sample to females who gave birth; the dependent variable is age at first birth. Columns (1) - (2) report the results using the pooled sample. Standard errors in parentheses are clustered at the village level.

\subsection{Living environment in adulthood}

This section discusses whether resettlement changes the children's current living environment. In Table 8, columns (1), (3), and (5) (columns (2), (4), and (6) present 
ITT (TOT) effects without other control variables. Table D6 in the Appendix reports the ITT and TOT estimates with other covariates included.

In panel A the benchmark estimates show that resettlement has no impact on the hukou status of the children using an aggregated sample or samples separated across gender. In Panel B the estimation restricts the sample to children who own housing property in 2018 (about 55\% of the whole sample). The benchmark ITT results show that the Boshan experiment decreased the children's housing property value by 160.49 thousand Chinese yuan. Most of these treatment effects are different from zero with $p<$ 0.01., Our results in Panel C show no effect on the probability of children living in more developed cities.

Overall, Table 8 shows that the resettlement does not seem to have improved the living quality of the children and their families. Third generation relocated migrants in the treatment group are more likely to be brought up in an area with lower housing values, which is often seen as an indicator of neighborhood quality.

Table 8: $\quad$ The impact of PAR on living environment

\begin{tabular}{lcccccc}
\hline & \multicolumn{2}{c}{ Pooled sample } & \multicolumn{2}{c}{ Boys } & \multicolumn{2}{c}{ Girls } \\
\cline { 2 - 7 } & \multicolumn{1}{c}{ ITT } & TOT & ITT & TOT & ITT & TOT \\
\cline { 2 - 7 } Panel A: Hukou & $(1)$ & $(2)$ & $(3)$ & $(4)$ & $(5)$ & $(6)$ \\
\cline { 2 - 7 } Exp. vs. control & -0.067 & -0.033 & -0.021 & 0.035 & -0.123 & -0.121 \\
& $(0.070)$ & $(0.068)$ & $(0.084)$ & $(0.119)$ & $(0.093)$ & $(0.111)$ \\
Observations & 179 & 179 & 93 & 93 & 86 & 86 \\
Control mean & 0.282 & 0.282 & 0.270 & 0.270 & 0.294 & 0.294 \\
Panel B: Housing value & Thousand yuan) & & & & -194.03 & -201.06 \\
Exp. vs. control & -160.49 & -393.04 & -137.52 & -163.00 & $-194.97)$ \\
& $(50.321)$ & $(148.38)$ & $(53.79)$ & $(67.23)$ & $(94.87)$ & $(84.97)$ \\
Observations & 104 & 104 & 58 & 58 & 46 & 46 \\
Control mean & 485.384 & 485.384 & 463.75 & 463.75 & 520.00 & 520.00 \\
Panel C: Rank of city & & & & & 0.004 \\
Exp. vs. control & -0.011 & -0.185 & -0.030 & -0.035 & -0.004 & 0.020 \\
& $(0.034)$ & $(0.162)$ & $(0.037)$ & $(0.051)$ & $(0.055)$ & $(0.048)$ \\
Observations & 179 & 179 & 93 & 93 & 86 & 86 \\
Control mean & 0.056 & 0.056 & 0.054 & 0.054 & 0.059 & 0.059 \\
\hline
\end{tabular}

Notes: The dependent variable in panel A is an indicator of having a non-agricultural hukou in 2018 . The dependent variable in panel $\mathrm{B}$ is the value of housing property in 2018. The dependent variable in panel $\mathrm{C}$ is the indicator of children living in a more developed city. Standard errors, reported in parentheses, are clustered at the village level.

\section{Conclusions and policy implications}

This study investigates the impact of a poverty alleviation resettlement experiment on children's development. For girls, the resettlement leads to worse short-term school performance and higher school dropout. Girls in the treatment group earn less in 
adulthood and are less likely to work in state-owned enterprises and public institutions than girls in the control group. The PAR experiment has no effect on marriage for females, but has an effect of earlier first birth. For boys, the PAR experiment has a negative impact on earnings in adulthood.

When people move from a remote mountainous area to places with more opportunities and better public resources, we expect the migrants' children to have improved outcomes. However, the PAR experiment might be a "spatial mismatch" (Kain 2004). Unlike the MTO program in US where people taking vouchers were free to move anywhere with a lower poverty rate, people in the Boshan PAR experiment were assigned to designated places. This might explain the negative outcomes we find. First, relocating to a community with better working opportunities for young workers might provide a negative incentive for investing in education, especially for girls, because of easier access to jobs. Children starting to work at early ages will provide families with short-term economic benefits, but not with long-term benefits from human capital accumulation through extended schooling. Second, there might be a skills mismatch. The design of the PAR program constrains the choices of the children, who grow up to work in nearby collective enterprises, and they might not fully develop their potential and productivity. Last, the businesses in Bohan prefecture, where most of the movers were working at the time of survey, were very profitable at the time of the 1994 resettlement. However, many of the state-owned and collective firms went bankrupt later due to the economic reform and industrial restructuring. Many collective enterprises were closed down or perform poorly. This also generates negative effects on children's employment and income since most of the movers worked for those firms and accumulated job skills that became less valuable.

Our study is not able to speak directly to today's poverty alleviation policies but it can generate insights into what government policymakers should take into consideration when implementing similar programs. The PAR experiment should have been more flexible and offered relocated families more choice, so that households could find the most suitable place for their development. The 'one-to-one'-type relocation limits children's development, even though the government in the destination village can provide relocated households with direct support under this moving mechanism. Chetty et al.'s (2014) study finds that the MTO program in the United States had a positive impact on young children's long-term development, which is in contrast to our results. This difference in outcomes might be strongly linked to the different flexibility under the two moving schemes. Relocation with free choice of destination allows movers to find a better 'match' than 'one-to-one' designated resettlement. Without completely removing the household registration constraint, a 'one-to-many' relocation program could be a second-best choice. 
The negative effects we identify seem to contradict the common belief that moving is always better. This could be related to the heterogenous impact across gender and generations. Government should be more careful about the potential different impacts on different groups of movers and the different short- and long-term impacts. Movers benefitted at the time of moving but moving can also lead to making bad choices, for various reasons.

Due to the culture norms of son preference in rural China, after resettlement parents might provide the best educational resources to boys, while girls might be sacrificed and withdrawn from school to find a job to support their family and might marry earlier, since both employment and the marriage market are better for young girls in suburban areas than in the mountainous regions. This could be addressed by providing girls with a high school scholarship or providing more education subsidies to reduce dropping out, and thus giving girls more opportunity to continue their education.

Last but not least, the current study has several important limitations. The sample size is too small to analyze the mechanisms underlying the findings, and the policy implications need to be evaluated carefully with a larger data set. Moreover, this study is an evaluation of a particular program in a specific location. The extent to which the findings can be generalized to another context is unclear. The data quality of individual information should be evaluated using administrative data. Our field survey experience found case studies and interviews to be interesting and valuable, and field surveys could be better documented for a deeper understanding of the life course development of resettled households through a non-statistical approach. Future research needs to address these issues.

\section{Acknowledgments}

We thank the guest editors, two anonymous referees, and participants at many conferences and seminars for their comments and suggestions. This research is supported by Fundamental Research Funds for the Central Universities (JBK1902038 and JBK1805007). 


\section{References}

Alexander, K.L., Entwisle, D.R., and Dauber, S.L. (1994). Children in motion: School transition and elementary school performance. Los Angeles, CA: American Sociological Association.

Alexander, K.L., Entwisle, D.R., and Olson, L.S. (2007). Lasting consequences of the summer learning gap. American Sociological Review 72(2): 167-180. doi:10.1177/000312240707200202.

Bauer, T., Braun, S., and Kvasnicka, M. (2012). The economic integration of forced migrants: Evidence for Post-War Germany. The Economic Journal 123(9): 9981024. doi:10.1111/ecoj.12023.

Bazzi, S., Gaduh, A., Rothenberg, A.D., and Wong, M. (2016). Skill transferability, migration, and development: Evidence from population resettlement in Indonesia. American Economic Review 106(9): 2658-2698. doi:10.1257/aer. 20141781.

Bergman, P., Chetty, R., DeLuca, S., Hendren, N., Katz, L.F., and Palmer, C. (2019). Creating moves to opportunity: Experimental evidence on barriers to neighborhood choice. Cambridge, MA: National Bureau of Economic Research (NBER Working Paper 26164). doi:10.3386/w26164.

Brooks, F., Zugazaga, C., Wolk, J., and Adams, M.A. (2005). Resident perceptions of housing, neighborhood, and economic conditions after relocation from public housing undergoing HOPE VI Redevelopment. Research on Social Work Practice 15(6): 481-490. doi:10.1177/1049731505276038.

Chetty, R. and Hendren, N. (2018). The impacts of neighborhoods on intergenerational mobility I: Childhood exposure effects. Quarterly Journal of Economic 133(3): 1107-1162. doi:10.1093/qje/qjy007.

Chetty, R., Hendren, N., and Katz, L.F. (2016a). The effects of exposure to better neighborhoods on children: New evidence from the Moving to Opportunity Experiment. American Economic Review 106(4): 855-902. doi:10.1257/ aer.20150572.

Chetty, R., Hendren, N., Kline, P., and Saez, E. (2014). Where is the land of opportunity? The geography of intergenerational mobility in the United States. Quarterly Journal of Economics 129(4): 1553-1623. doi:10.1093/qje/qju022. 
Chetty, R., Hendren, N., Lin, F., Majerovitz, J., and Scuderi, B. (2016b). Childhood environment and gender gaps in adulthood. American Economic Review 106(5): 282-288. doi:10.1257/aer.p20161073.

Chyn, E. (2018). Moved to opportunity: The long-run effects of public housing demolition on children. American Economic Review 108(10): 3028-3056. doi:10.1257/aer.20161352.

Davis, M.A., Gregory, J., and Hartley, D.A. (2019). The long-run effects of low-income housing on neighborhood composition [unpublished manuscript]. https://www.ssc.wisc.edu/ jmgregory/DGTcurrent.pdf.

DeLuca, S. and Rosenblatt, P. (2017). Walking away from the wire: Housing mobility and neighborhood opportunity in Baltimore. Housing Policy Debate 27(4): 519546. doi:10.1080/10511482.2017.1282884.

Falck, O., Heblich, S., and Link, S. (2011) The evils of forced migration: Do integration policies alleviate migrants' economic situations? (IZA Discussion Paper 5829).

Gobillon, L. and Selod, H. (2007). The effect of segregation and spatial mismatch on unemployment: Evidence from France (CEPR Discussion Paper 6198).

Holzer, H. (1991). The spatial mismatch hypothesis: What has the evidence shown? Urban Studies 28: 105-122. doi:10.1080/00420989120080071.

Ihlanfeldt, K. (2006). A primer on spatial mismatch within urban labor markets. In: Arnott, R.J. and Mcmillen, D.P. (eds.) A companion to urban economics. Oxford: Blackwell Publishing: 404-417. doi:10.1002/9780470996225.ch24.

Ihlanfeldt, K. and Sjoquist, D. (1998). The spatial mismatch hypothesis: A review of recent studies and their implications for welfare reform. Housing Policy Debate 9: 849-892. doi:10.1080/10511482.1998.9521321.

Immergluck, D. (1998). Job proximity and the urban employment problem: Do suitable nearby jobs improve neighborhood employment rates? Urban Studies 35: 7-23. doi:10.1080/0042098985041.

Ingersoll, G., Scamman, J., and Eckerling W.D. (1989). Geographic mobility and student achievement in an urban setting. Educational Evaluation and Policy Analysis 11(2): 143-149. doi:10.3102/01623737011002143.

Jacob, B.A. (2004). Public housing, housing vouchers, and student achievement: evidence from public housing demolitions in Chicago. American Economic Review 94(1): 233-258. doi:10.1257/000282804322970788. 
Kain, J. (1968). Housing segregation, negro employment, and metropolitan decentralization. Quarterly Journal of Economics 82: 175-197. doi:10.2307/ 1885893.

Kain, J. (1992). The spatial mismatch hypothesis: Three decades later. Housing Policy Debate 3: 371-460. doi:10.1080/10511482.1992.9521100.

Kain, J. (2004). A pioneer's perspective on the spatial mismatch literature. Urban Studies 41: 7-32. doi:10.1080/0042098032000155669.

Kasarda, J. (1985). Urban change and minority opportunities. In: Peterson, P. (ed.). The new urban reality. Washington, D.C.: Brookings Institution: 33-67.

Kasarda, J. (1988). Jobs, migration, and emerging urban mismatches. In: Mcgeary, M.G.H. and Lynn, Jr., L.E. (eds.). Urban change and poverty. Washington, D.C.: National Academy Press: 148-188. doi:10.17226/1096.

Kasarda, J. (1989). Urban industrial transition and the underclass. Annals of the American Academy of Political Science 501: 26-47. doi:10.1177/00027162 89501001002.

Kling, J.R., Ludwig, J., and Katz, L.F. (2005). Neighborhood effects on crime for female and male youth: Evidence from a randomized housing voucher experiment. Quarterly Journal of Economics 120(1): 87-130. doi:10.1162/00 33553053327470 .

Kumar, A. (2013). Preference based vs. market based discrimination: Implications for gender differentials in child labor and schooling. Journal of Development Economics 105: 64-68. doi:10.1016/j.jdeveco.2013.07.004.

Lambert, S. and Rossi, P. (2016). Sons as widowhood insurance: Evidence from Senegal. Journal of Development Economics 120: 113-127. doi:10.1016/j. jdeveco.2016.01.004.

Lo, K. and Wang, M. (2018). How voluntary is poverty alleviation resettlement in China? Habitat International 73: 34-42. doi:10.1016/j.habitatint.2018.01.002.

Meng, X. and Yamauchi, C. (2017). Children of migrants: The cumulative impact of parental migration on children's education and health outcomes in China. Demography 54: 1677-1714. doi:10.1007/s13524-017-0613-z.

National Bureau of Statistics of China (2018). [electronic resource]. http://data.stats.gov.cn/easyquery.htm? $\mathrm{cn}=\mathrm{C} 01$. 
Ning, J., Yin, H.D., and Wang, S.G. (2018). Does poverty alleviation relocation reduce poverty vulnerability. China Population, Resources and Environment 28(11): $20-28$.

Ong, P. and Blumenberg, E. (1998). Job access, commute and travel burden among welfare recipients. Urban Studies 35(1): 77-93. doi:10.1080/0042098985087.

Ruiz, I. and Vargas-Silva, C. (2013) The economics of forced migration. Journal of Development Studies 49(6): 772-784.

Wang, X., Bai, Y., Zhang, L., Rozelle, S. (2017). Migration, schooling choice, and student outcomes in China. Population and Development Review 43(4): 625643. doi:10.1111/padr.12101.

Wheeler, L. (1993). A review of the spatial mismatch hypothesis: Its impact on the current plight of the central city in the United States. (Occasional Paper 137). Metropolitan Studies Program, Maxwell School of Citizenship and Public Affairs, Syracuse University.

Wilson, J. (1987). The truly disadvantaged: The inner city, the underclass, and public policy. Chicago: University of Chicago Press.

Wilson, J. (1996). When work disappears: The world of the new urban poor. New York: Knopf. doi:10.2307/2152085.

$\mathrm{Xu}, \mathrm{H}$. and Xie, Y. (2015). The causal effects of rural-to-urban migration on children's well-being in China. European Sociological Review 31(4): 502-519. doi:10.1093/esr/jev009.

Xue, L.Y., Wang, M.Y., and Xue, T. (2013). 'Voluntary' poverty alleviation resettlement in China. Development and Change 44(5): 1159-1180. doi:10.1111/dech.12054.

Yin, H.D., Wang, Y., and Wand, S.G. (2017). Identification of poverty alleviation relocation households: Multidimensional poverty measurement and its decomposition. China Population, Resources and Environment 27(11): 104114.

Yue, A., Bai, Y., Shi, Y., Luo, R.F., Rozelle, S., Medina, A., and Sylvia, S. (2020). Parental migration and early childhood development in rural China. Demography 3: 1-20. doi:10.1007/s13524-019-00849-4.

Zhang, J.P., Wang, R., and Lu, C. (2019). A quantitative analysis of Hukou reform in Chinese cities: 2000-2016. Growth and Change 50(1): 201-221. doi:10.1111/ grow.12284. 
Zhu, L. and Ma, C. (2016). China tackles poverty by resettling rural villagers [electronic resource]. China Daily http://usa.chinadaily.com.cn/china/201606/30/content_25914292.htm.

Zibo Government (2019). http://www.zibo.gov.cn/ [electronic resource]. 


\section{Appendix A: Power analysis, treatment and control villages}

We conducted a power analysis to check the sample size requirement. With a $10 \%$ significance level and 0.8 acceptable power level, the estimated sample size for a twosample means test is 150, as shown in Figure A-4. It implies that our sample size (179) is sufficient.

\section{Appendix B: Data accuracy and collection}

The research team worked carefully to ensure data accuracy. First, the survey was conducted during the Chinese Spring Festival when migrant children often return to visit their parents (the first generation of resettled migrants). Thus, we had a better chance to perform face-to-face interviews and ensure the accuracy of information. Second, online surveys were used as a supplementary method. If a face-to-face interview could not be conducted, after obtaining current contact information from their parents, an online survey was sent directly to the children through the online platform Wechat. Third, we tried to use different channels to double-check the quality of the survey, including interviewing the parents and phone calls to the interviewee. For the online survey, once the interviewee finished their submission a research assistant checked the data and provided feedback on missing data and outliers. The interviewer then contacted the reference person by phone to fill in the missing information and double check the accuracy of the answer. Lastly, with support from the local government, we were able to obtain Boshan archive information on the villages and a list of the children that moved, including detailed information on the number of households, the area of land, schooling, age, and marriage status of migrants at the time of resettlement.

A major challenge during the field survey was that some households, both children and parents, had moved out of the Boshan area during the past 20 years. Mostly, this could be addressed by asking relatives in the village or other villagers, since especially the older villagers, i.e., the first generation of migrants, maintain social connections with each other. In rural areas extended families with the same surname or blood ties tend to live together or close to each other. Therefore, even though families had moved out, we were able to obtain their current contact information from relatives or old neighbors. 


\section{Appendix C: Observational evidence from interviewers}

\section{The gender difference in education}

After moving from the mountainous area to suburban areas, public resources like schools and transportation are better. However, the PAR benefits boys, while girls are worse off. This is related to the long-existing son preference in rural China. After the resettlement, girls often gave up the opportunity of further education and chose to find a job at an early age, resulting in a higher school dropout rate. The following is an example from our interviewers.

I interviewed a girl who complained about her parents. "I used to be doing well in my studies, but after the resettlement they (parents) persuaded me to quit school and find a job as soon as possible... My younger brother has not married yet, I need to earn money to help my parents save for his marriage in the future. I need to prepare for my dowry as well."

Most parents seem to agree that 'A married girl is like pouring water out and never getting it back'.... After the resettlement the parents find a job and obtain a higher salary than before, they are prepared to pay tuition fees for their boys but not for girls to have a high school or college education. (From interviewer.)

I interviewed children in the control group; they tend to be strongly motivated to study. A boy told me "My whole family counts on me. My family does not have many social connections, they are simple farmers ... they cannot help me find a job in downtown. I have to study hard to attend high school and college to find a better job myself." (From interviewer.)

\section{The mismatch of job skills}

There is a serious job-skill mismatch issue in the Boshan PAR. After the resettlement the new jobs required different skills than previously. Here is some observational evidence from our interviewers.

Mining was a pillar industry in Boshan. However, coal resources depleted in the late 1990s and many coal businesses were closed. Boshan GDP decreased dramatically after that. Many people who used to work in the mining industry were forced to find other jobs. 
Zhan, Zhang \& Lu: Long-run effects of poverty alleviation resettlement on child development

Recently, local government enacted stringent environmental standards on water pollution, many polluting factories were forced to close. Thus, people were laid off or switched from full-time to part-time work. A former factory worker told me, "Government often checks pollutant emissions during daytime, so we had to work at midnight ... During the daytime, I worked as a part-time taxi driver to support my family."

\section{Appendix D}

Table D1: The short-run impact on educational outcome with control variables included

\begin{tabular}{|c|c|c|}
\hline & \multicolumn{2}{|c|}{ Short-term education } \\
\hline & ITT & TOT \\
\hline & (1) & $(2)$ \\
\hline \multicolumn{3}{|c|}{ Panel A: Pooled sample } \\
\hline \multirow[t]{2}{*}{ Exp. vs. control } & 0.113 & 0.130 \\
\hline & $(0.221)$ & $(0.233)$ \\
\hline Observations & 117 & 117 \\
\hline Control means & 2.654 & 2.654 \\
\hline \multicolumn{3}{|l|}{ Panel B: Boys } \\
\hline \multirow[t]{2}{*}{ Exp. vs. control } & -0.199 & -0.264 \\
\hline & $(0.310)$ & $(0.371)$ \\
\hline Observations & 68 & 68 \\
\hline Control means & 2.767 & 2.767 \\
\hline \multicolumn{3}{|l|}{ Panel C: Girls } \\
\hline \multirow[t]{2}{*}{ Exp. vs. control } & 0.610 & 0.831 \\
\hline & $(0.314)$ & $(0.412)$ \\
\hline Observations & 49 & 49 \\
\hline Control means & 2.5 & 2.5 \\
\hline
\end{tabular}

Notes: Columns (1) and (2) report the ITT estimates and TOT estimates without control variables, separately. Panel A reports the results using a pooled sample; panel $\mathrm{B}$ and panel $\mathrm{C}$ report estimates for boys and girls separately. Z-scores are calculated by subtracting the control group mean and dividing by the control group standard deviation. The higher the score (negatively related to GPA in raw data), the worse the performance. Samples are restricted to children who enrolled in school in 1994. Standard errors, reported in parentheses, are clustered by village. For all the specifications, the regional indicators are included. 


\section{Table D2: Continuing education after nine-year compulsory education}

\begin{tabular}{|c|c|c|c|c|c|c|}
\hline & \multicolumn{2}{|c|}{ Pooled sample } & \multicolumn{2}{|c|}{ Boys } & \multicolumn{2}{|c|}{ Girls } \\
\hline & ITT & TOT & ITT & TOT & ITT & TOT \\
\hline & $(1)$ & $(2)$ & (3) & $(4)$ & $(5)$ & (6) \\
\hline \multicolumn{7}{|c|}{ Panel A: The high school entrance exam participation rate $(Y e s=1 ; N o=0)$} \\
\hline \multirow[t]{2}{*}{ Exp. vs. control } & -0.180 & -0.224 & -0.263 & -0.367 & -0.217 & -0.151 \\
\hline & $(0.092)$ & $(0.109)$ & $(0.145)$ & $(0.192)$ & $(0.105)$ & $(0.121)$ \\
\hline Observations & 179 & 179 & 95 & 95 & 78 & 78 \\
\hline Control mean & 0.647 & 0.647 & 0.667 & 0.667 & 0.625 & 0.625 \\
\hline \multicolumn{7}{|c|}{ Panel B: High school attendance rate $(Y e s=1, N=0)$} \\
\hline \multirow[t]{2}{*}{ Exp. vs. control } & -0.161 & -0.224 & -0.192 & -0.294 & -0.177 & -0.188 \\
\hline & $(0.091)$ & $(0.100)$ & $(0.111)$ & $(0.145)$ & $(0.112)$ & $(0.114)$ \\
\hline Observations & 172 & 172 & 89 & 89 & 83 & 83 \\
\hline Control mean & 0.454 & 0.454 & 0.441 & 0.441 & 0.468 & 0.468 \\
\hline \multicolumn{7}{|c|}{ Panel C: Ranking in high school entrance exam (Z-score) } \\
\hline \multirow[t]{2}{*}{ Exp. vs. control } & 0.083 & 0.087 & 0.032 & 0.037 & 0.065 & 0.066 \\
\hline & $(0.251)$ & $(0.262)$ & $(0.454)$ & $(0.452)$ & $(0.541)$ & $(0.521)$ \\
\hline Observations & 110 & 110 & 61 & 61 & 49 & 49 \\
\hline Control mean & 2.909 & 2.909 & 3 & 3 & 2.8 & 2.8 \\
\hline \multicolumn{7}{|c|}{ Panel D: School dropout rate } \\
\hline \multirow[t]{2}{*}{ Exp. vs. control } & 0.128 & 0.157 & 0.081 & 0.111 & 0.160 & 0.192 \\
\hline & $(0.068)$ & $(0.087)$ & $(0.097)$ & $(0.132)$ & $(0.071)$ & $(0.095)$ \\
\hline Observations & 179 & 179 & 93 & 93 & 86 & 86 \\
\hline Control mean & 0.113 & 0.113 & 0.081 & 0.081 & 0.147 & 0.147 \\
\hline
\end{tabular}

Notes: Columns (1), (3), and (5) report ITT estimates from OLS regressions of an outcome on indicators for being assigned to the treatment group and regional dummies with control variables; columns (2), (4), and (6) report TOT estimates from 2SLS estimation of an outcome on indicators for being assigned to the treatment group and regional dummies with control variables; Columns (1) and (2) report the results using a pooled sample; columns (3) and (4) restrict the samples to boys; columns (5) and (6) restrict the samples to girls. Standard errors, reported in parentheses, are clustered at the village level. The dependent variable in panel $\mathrm{A}$ indicates participation in the high school entrance exam. The dependent variable in panel B indicates high/technical school attendance rate. The dependent variable in Panel C is a categorical variable of self-ranking scores in the high school entrance exam, and Panel $C$ restricts samples to children who have scores in the entrance exam. The dependent variable in panel $D$ is the school dropout rate. A regional indicator is included in all the specifications. 
Zhan, Zhang \& Lu: Long-run effects of poverty alleviation resettlement on child development

Table D3: The impact of PAR on income

\begin{tabular}{|c|c|c|c|c|c|c|}
\hline & \multicolumn{2}{|c|}{ Pooled sample } & \multicolumn{2}{|c|}{ Boys } & \multicolumn{2}{|c|}{ Girls } \\
\hline & ITT & TOT & ITT & TOT & ITT & TOT \\
\hline & (1) & $(2)$ & (3) & $(4)$ & (5) & (6) \\
\hline \multicolumn{7}{|c|}{ Panel A: Personal income in 2018} \\
\hline Exp. vs. control & $\begin{array}{c}-0.809 \\
(0.328)\end{array}$ & $\begin{array}{c}-0.927 \\
(0.451)\end{array}$ & $\begin{array}{c}-0.765 \\
(0.445)\end{array}$ & $\begin{array}{c}-0.812 \\
(0.587)\end{array}$ & $\begin{array}{r}-903 \\
\quad(0.499)\end{array}$ & $\begin{array}{l}-0.557 \\
(0.406)\end{array}$ \\
\hline Observations & 179 & 179 & 90 & 90 & 78 & 78 \\
\hline Control mean & 3.821 & 3.821 & 4.444 & 4.444 & 3.097 & 3.097 \\
\hline \multicolumn{7}{|c|}{ Panel B: Personal income in 2016} \\
\hline Exp. vs. control & $\begin{array}{c}-0.584 \\
(0.311)\end{array}$ & $\begin{array}{c}-0.626 \\
(0.398)\end{array}$ & $\begin{array}{c}-0.562 \\
(0.368)\end{array}$ & $\begin{array}{c}-0.459 \\
(0.523)\end{array}$ & $\begin{array}{c}-0.576 \\
(0.360)\end{array}$ & $\begin{array}{c}-0.811 \\
(0.430)\end{array}$ \\
\hline Observations & 179 & 179 & 90 & 90 & 78 & 78 \\
\hline Control mean & 3.418 & 3.418 & 3.639 & 3.639 & 3.161 & 3.161 \\
\hline \multicolumn{7}{|c|}{ Panel C: Personal income in 2014} \\
\hline Exp. vs. control & $\begin{array}{c}-0.606 \\
(0.271)\end{array}$ & $\begin{array}{c}-0.565 \\
(0.355)\end{array}$ & $\begin{array}{c}-0.651 \\
(0.380)\end{array}$ & $\begin{array}{c}-0.571 \\
(0.536)\end{array}$ & $\begin{array}{c}-0.446 \\
(0.318)\end{array}$ & $\begin{array}{c}-0.495 \\
(0.356)\end{array}$ \\
\hline Observations & 179 & 179 & 90 & 90 & 78 & 78 \\
\hline Control mean & 3.045 & 3.045 & 3.306 & 3.306 & 2.742 & 2.742 \\
\hline \multicolumn{7}{|c|}{ Panel D: Average personal income (2014, 2016, and 2018) } \\
\hline Exp. vs. control & $\begin{array}{c}-0.667 \\
(0.289)\end{array}$ & $\begin{array}{c}-0.706 \\
(0.384)\end{array}$ & $\begin{array}{c}-0.659 \\
(0.380)\end{array}$ & $\begin{array}{c}-0.614 \\
(0.531)\end{array}$ & $\begin{array}{c}-0.526 \\
(0.309)\end{array}$ & $\begin{array}{c}-0.688 \\
(0.367)\end{array}$ \\
\hline Observations & 179 & 179 & 90 & 90 & 78 & 78 \\
\hline Control mean & 3.428 & 3.428 & 3.796 & 3.796 & 3.000 & 3.000 \\
\hline \multicolumn{7}{|c|}{ Panel E: Average personal income (Chinese yuan) - robustness check } \\
\hline Exp. vs. control & $\begin{array}{r}-1014.2 \\
(459.4)\end{array}$ & $\begin{array}{r}-1117.0 \\
(621.2)\end{array}$ & $\begin{array}{r}-1148.2 \\
(610.1)\end{array}$ & $\begin{array}{r}-1208.6 \\
(871.9)\end{array}$ & $\begin{array}{c}-674.5 \\
(401.2)\end{array}$ & $\begin{array}{c}-901.2 \\
(476.3)\end{array}$ \\
\hline Observations & 179 & 179 & 90 & 90 & 78 & 78 \\
\hline Control mean & 3595 & 3595 & 4162 & 4162 & 2935.5 & 2935.5 \\
\hline
\end{tabular}

Notes: Income is a categorical variable from low to high. Personal income includes all wage income, self-employed income, social transfers, and investment income before tax. Columns (1), (3), and (5) report ITT estimates from OLS regressions of an outcome on indicators for being assigned to the treatment group and regional dummies with control variables; columns (2), (4), and (6) report TOT estimates from 2SLS estimation of an outcome on indicators for being assigned to the treatment group and regional dummies with control variables; Columns (1) and (2) report the results using a pooled sample; columns (3) and (4) restrict the samples to boys; columns (5) and (6) restrict the samples to girls. Standard errors, reported in parentheses, are clustered at the village level. Standard errors, reported in parentheses, are clustered at the village level. The dependent variable in panel A is the individual's income in 2018 (categorical variable). The dependent variable in panel B is the individual's income in 2016 (categorical variable). The dependent variable in Panel $C$ is the individual's income in 2015 (categorical variable). The dependent variable in Panel $D$ is the individual's 5-year average income (categorical variable). The dependent variable in Panel E is income measured in Chinese yuan, taking the medium value of the income bracket. 
Table D4: The impact of PAR on job selection

\begin{tabular}{|c|c|c|c|c|c|c|}
\hline & \multicolumn{2}{|c|}{ Pooled sample } & \multicolumn{2}{|c|}{ Boys } & \multicolumn{2}{|c|}{ Girls } \\
\hline & ITT & TOT & ITT & TOT & ITT & TOT \\
\hline & (1) & $(2)$ & (3) & $(4)$ & (5) & (6) \\
\hline \multicolumn{7}{|c|}{ Panel A: Entrepreneurship $(\overline{Y e s}=1, N o=0)$} \\
\hline \multirow[t]{2}{*}{ Exp. vs. control } & 0.014 & 0.022 & -0.063 & -0.066 & -0.038 & -0.041 \\
\hline & $(0.077)$ & $(0.083)$ & $(0.098)$ & $(0.103)$ & $(0.077)$ & $(0.079)$ \\
\hline Observations & 179 & 179 & 93 & 93 & 86 & 86 \\
\hline Control mean & 0.183 & 0.183 & 0.243 & 0.243 & 0.118 & 0.118 \\
\hline \multicolumn{7}{|c|}{ Panel B: Farm work (yes=1, No=0) } \\
\hline \multirow[t]{2}{*}{ Exp. vs. control } & -0.021 & -0.033 & -0.029 & -0.031 & -0.084 & -0.079 \\
\hline & $(0.076)$ & $(0.083)$ & $(0.058)$ & $(0.061)$ & $(0.088)$ & $(0.090)$ \\
\hline Observations & 179 & 179 & 93 & 93 & 86 & 86 \\
\hline Control mean & 0.070 & 0.070 & 0.054 & 0.054 & 0.088 & 0.088 \\
\hline \multicolumn{7}{|c|}{ Panel C: Public-owned company/foreign-owned company (yes=1, No=0) } \\
\hline \multirow[t]{2}{*}{ Exp. vs. control } & -0.192 & -0.240 & -0.321 & -0.412 & -0.067 & -0.104 \\
\hline & $(0.100)$ & (0.0113) & $(0.169)$ & $(0.210)$ & $(0.085)$ & $(0.088)$ \\
\hline Observations & 179 & 179 & 93 & 93 & 86 & 86 \\
\hline Control mean & 0.225 & 0.225 & 0.270 & 0.270 & 0.176 & 0.270 \\
\hline
\end{tabular}

Notes: Columns (1), (3), and (5) report ITT estimates from OLS regressions of an outcome on indicators for being assigned to the treatment group and regional dummies with control variables; columns (2), (4), and (6) report TOT estimates from 2SLS estimation of an outcome on indicators for being assigned to the treatment group and regional dummies with control variables; Columns (1) and (2) report the results using a pooled sample; columns (3) and (4) restrict the samples to boys; columns (5) and (6) restrict the samples to girls. Standard errors, reported in parentheses, are clustered at the village level. The dependent variable in panel A indicates starting a business. The dependent variable in panel $\mathrm{B}$ indicates being a farmer. The dependent variable in Panel $\mathrm{C}$ is a binary choice variable of working in a publicly owned, foreign-invested company, and public institution.

\section{Table D5: The impact of PAR on marriage and fertility}

\begin{tabular}{|c|c|c|c|c|c|c|}
\hline & \multicolumn{2}{|c|}{ Pooled sample } & \multicolumn{2}{|c|}{ Boys } & \multicolumn{2}{|c|}{ Girls } \\
\hline & ITT & TOT & ITT & TOT & ITT & TOT \\
\hline & $(1)$ & $(2)$ & $(3)$ & $(4)$ & $(5)$ & $(6)$ \\
\hline \multicolumn{7}{|c|}{ Panel A: Marriage (marriage $=1$, other $=0$ ) } \\
\hline \multirow[t]{2}{*}{ Exp. vs. control } & 0.031 & 0.064 & 0.011 & 0.036 & 0.041 & 0.082 \\
\hline & $(0.052)$ & $(0.066)$ & $(0.057)$ & $(0.082)$ & $(0.080)$ & $(0.092)$ \\
\hline Observations & 179 & 179 & 93 & 93 & 86 & 86 \\
\hline Control mean & 0.859 & 0.859 & 0.918 & 0.918 & 0.794 & 0.794 \\
\hline \multicolumn{7}{|c|}{ Panel B: Divorce (divorce $=1$, other $=0$ ) } \\
\hline \multirow[t]{2}{*}{ Exp. vs. control } & -0.056 & -0.081 & -0.059 & -0.097 & 0.040 & 0.055 \\
\hline & $(0.053)$ & $(0.073)$ & $(0.046)$ & $(0.069)$ & $(0.067)$ & $(0.080)$ \\
\hline Observations & 179 & 179 & 93 & 93 & 86 & 86 \\
\hline Control mean & 0.070 & 0.070 & 0.054 & 0.054 & 0.088 & 0.088 \\
\hline \multicolumn{7}{|c|}{ Panel C: First Birth (age at) } \\
\hline \multirow[t]{2}{*}{ Exp. vs. control } & -- & -- & -- & -- & -1.459 & -1.748 \\
\hline & -- & -- & -- & -- & $(0.773)$ & $(0.835)$ \\
\hline Observations & -- & -- & -- & -- & 69 & 69 \\
\hline Control mean & -- & -- & - & -- & 25.840 & 25.840 \\
\hline
\end{tabular}

Notes: Columns (1), (3), and (5) report ITT estimates from OLS regressions of an outcome on indicators for being assigned to the treatment group and regional dummies with control variables; columns (2), (4), and (6) report TOT estimates from 2SLS estimation of an outcome on indicators for being assigned to the treatment group and regional dummies with control variables; Columns (1) and (2) report the results using a pooled sample; columns (3) and (4) restrict the samples to boys; columns (5) and (6) restrict the samples to girls. Standard errors, reported in parentheses, are clustered at the village level. The dependent variable in panel A indicates being married in 2018. The dependent variable in panel B indicates being divorced in 2018. Panel C restricts the sample to females who have given birth; the dependent variable is the age of the female at first birth. 
Zhan, Zhang \& Lu: Long-run effects of poverty alleviation resettlement on child development

Table D6: The impact of PAR on living environment

\begin{tabular}{|c|c|c|c|c|c|c|}
\hline & \multicolumn{2}{|c|}{ Pooled sample } & \multicolumn{2}{|c|}{ Boys } & \multicolumn{2}{|c|}{ Girls } \\
\hline & ITT & TOT & ITT & TOT & ITT & TOT \\
\hline & (1) & $(2)$ & (3) & $(4)$ & (5) & $(6)$ \\
\hline \multicolumn{7}{|l|}{ Panel A: Hukou } \\
\hline Exp. vs. control & $\begin{array}{c}-0.085 \\
(0.089)\end{array}$ & $\begin{array}{c}-0.007 \\
(0.087)\end{array}$ & $\begin{array}{c}-0.029 \\
(0.112)\end{array}$ & $\begin{array}{c}0.134 \\
(0.158)\end{array}$ & $\begin{array}{c}-0.148 \\
(0.107)\end{array}$ & $\begin{array}{c}-0.172 \\
(0.130)\end{array}$ \\
\hline Observations & 179 & 179 & 93 & 93 & 86 & 86 \\
\hline Control mean & 0.282 & 0.282 & 0.270 & 0.270 & 0.294 & 0.294 \\
\hline \multicolumn{7}{|c|}{ Panel B: Housing value } \\
\hline Exp. vs. control & $\begin{array}{r}-208.64 \\
(73.03)\end{array}$ & $\begin{array}{r}-241.92 \\
(73.27)\end{array}$ & $\begin{array}{r}-193.64 \\
(75.75)\end{array}$ & $\begin{array}{r}-224.99 \\
(85.35)\end{array}$ & $\begin{array}{c}-234.45 \\
(119.54)\end{array}$ & $\begin{array}{r}-243.73 \\
(80.37)\end{array}$ \\
\hline Observations & 104 & 104 & 58 & 58 & 46 & 46 \\
\hline Control mean & 485.384 & 485.384 & 463.75 & 463.75 & 520.00 & 520.00 \\
\hline \multicolumn{7}{|c|}{ Panel C: Rank of city } \\
\hline Exp. vs. control & $\begin{array}{r}-0.013 \\
(0.043)\end{array}$ & $\begin{array}{r}-0.010 \\
(0.045)\end{array}$ & $\begin{array}{c}-0.041 \\
(0.051)\end{array}$ & $\begin{array}{r}-0.049 \\
(0.067)\end{array}$ & $\begin{array}{c}-0.005 \\
(0.064)\end{array}$ & $\begin{array}{c}0.024 \\
(0.052)\end{array}$ \\
\hline Observations & 179 & 179 & 93 & 93 & 86 & 86 \\
\hline Control mean & 0.056 & 0.056 & 0.054 & 0.054 & 0.059 & 0.059 \\
\hline
\end{tabular}

Notes: Columns (1), (3), and (5) report ITT estimates from OLS regressions of an outcome on indicators for being assigned to the treatment group and regional dummies with control variables; columns (2), (4), and (6) report TOT estimates from 2SLS estimation of an outcome on indicators for being assigned to the treatment group and regional dummies with control variables; Columns (1) and (2) report the results using a pooled sample; columns (3) and (4) restrict the samples to boys; columns (5) and (6) restrict the samples to girls. Standard errors, reported in parentheses, are clustered at the village level. The dependent variable in panel $\mathrm{A}$ indicates having a non-agricultural hukou in 2018. The dependent variable in panel B is housing price in 2018 for children owning real estate. The dependent variable in panel $\mathrm{C}$ indicates children living in a most-developed city. 
Figure A-1: Comparison of income per capita at the village level in 1994

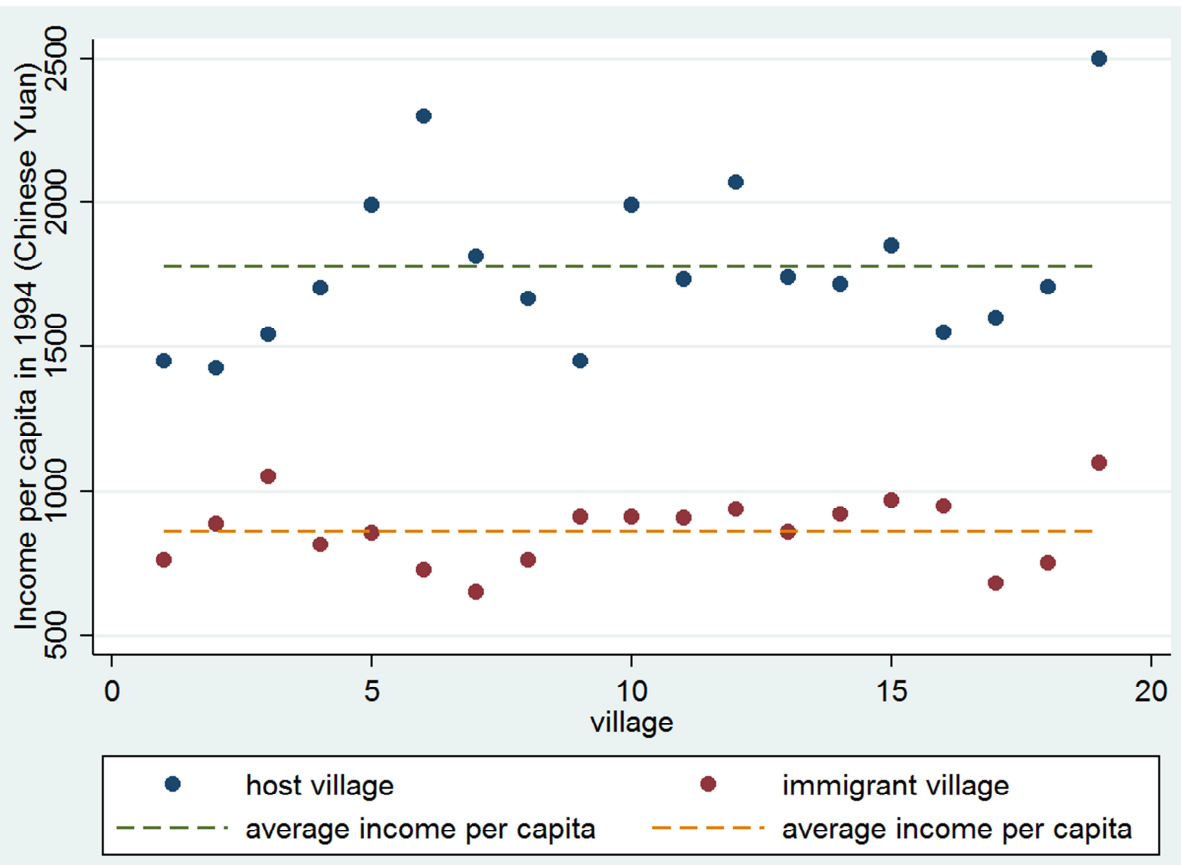


Zhan, Zhang \& Lu: Long-run effects of poverty alleviation resettlement on child development

Figure A-2: Comparison of cultivated land at the village level in 1994

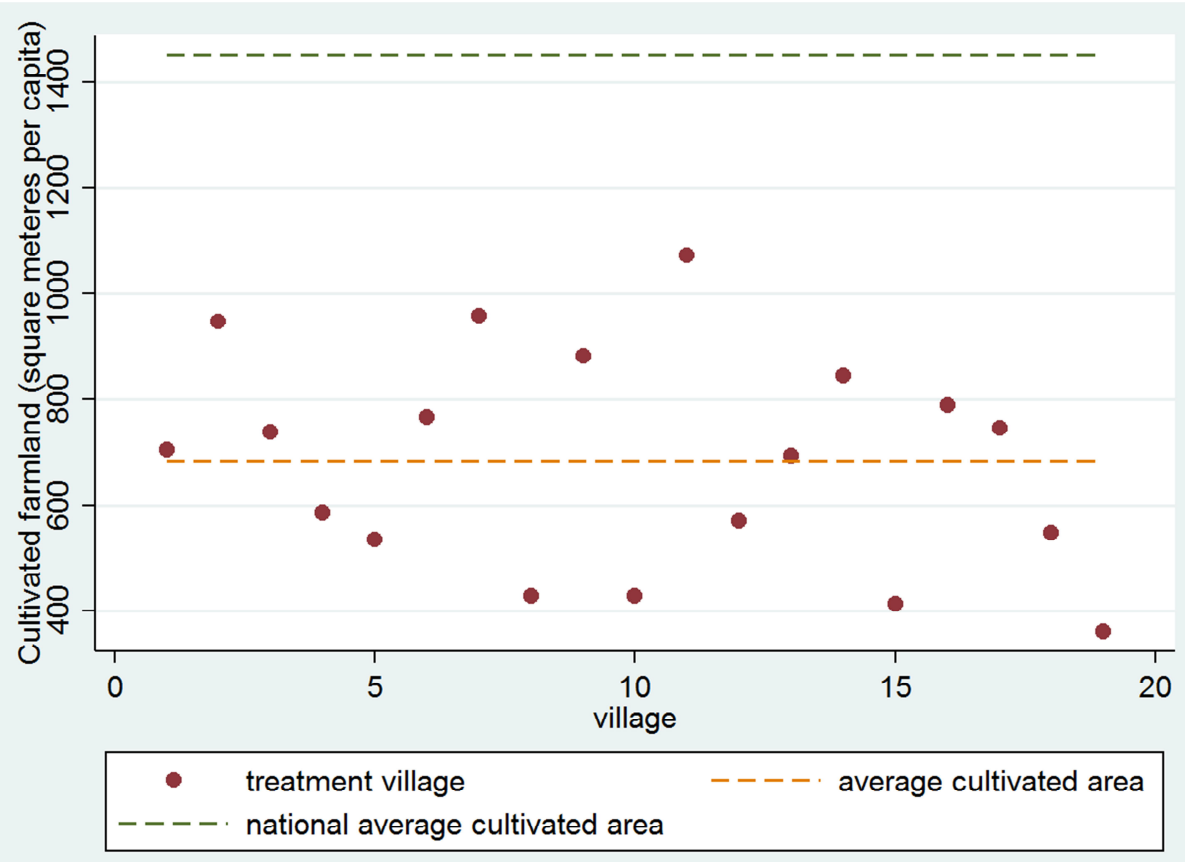




\section{Figure A-3: Location of control and treated villages in Boshan Distrct}

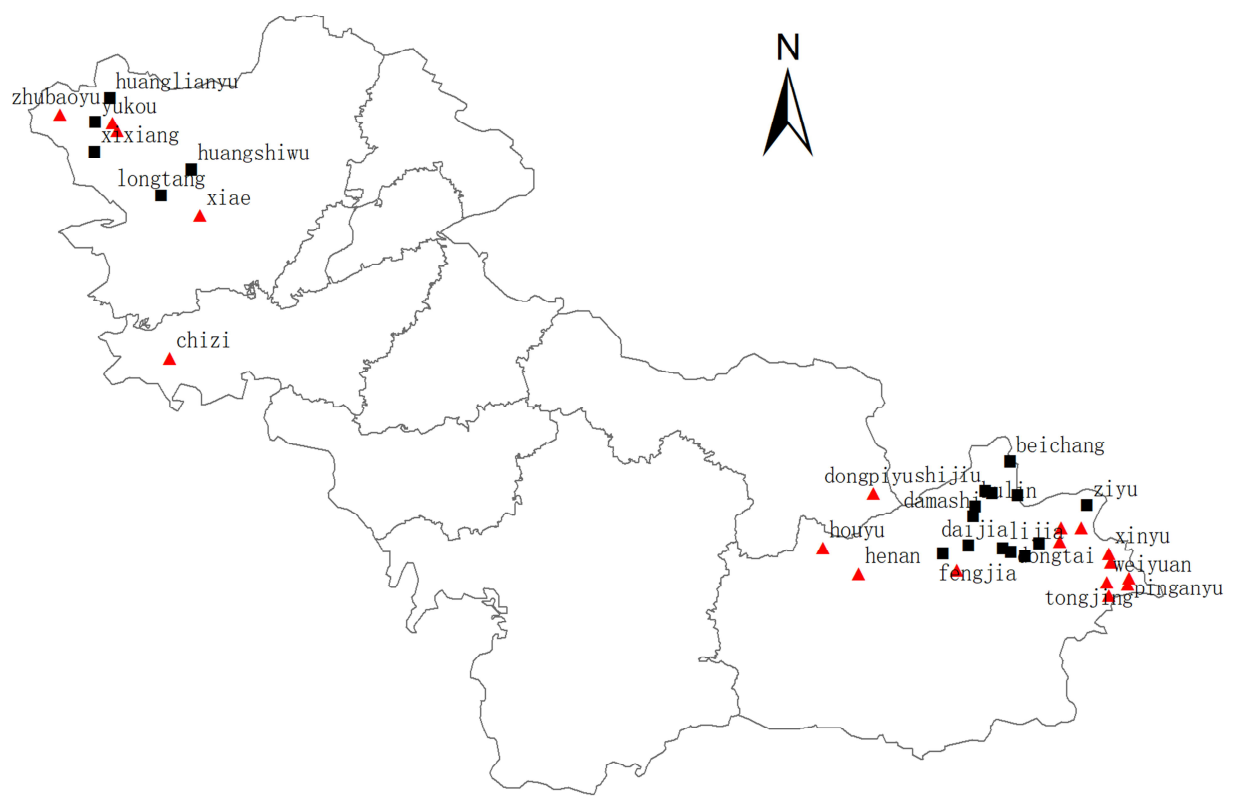

Note: The black squares represent the control villages, and the red triangles represent the treated villages. 


\section{Figure A-4: Sample size of power analysis}

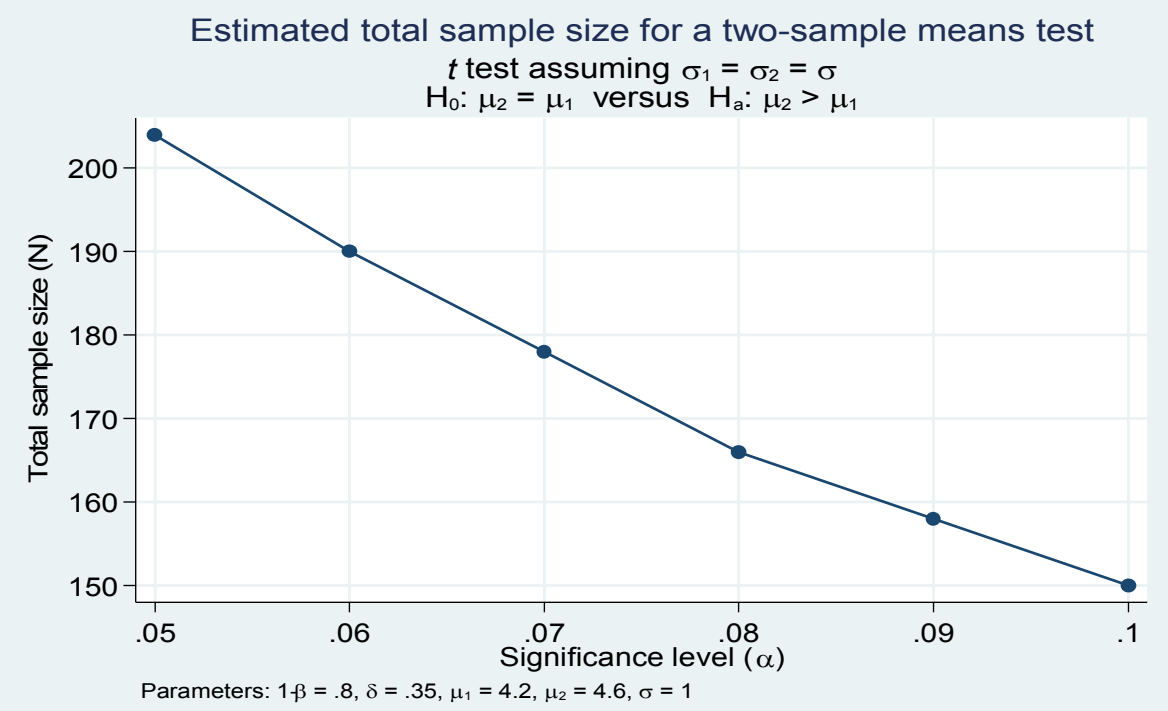

